\title{
A Linuron-Free Weed Management Strategy for Carrots
}

\author{
by
}

Tessa Johnna de Boer

\author{
A Thesis \\ presented to \\ The University of Guelph
}
In partial fulfilment of requirements
for the degree of
Master of Science
in
Plant Agriculture

Guelph, Ontario, Canada

(C) Tessa de Boer, April, 2018 


\section{ABSTRACT}

\section{A LINURON-FREE WEED MANAGEMENT STRATEGY FOR CARROTS}

\section{Tessa Johnna de Boer University of Guelph, 2018}

\section{Advisor: \\ Professor Clarence Swanton}

The development of a linuron-free weed management strategy for carrot production is essential as a result of the herbicide re-evaluation programs launched by the Pest Management Regulatory Agency in Canada for herbicides registered prior to 1995 and the recent discovery of linuron resistant pigweed species in Ontario. In 2016 and 2017 field trials were conducted in one of Ontario's main carrot growing regions on high organic soils. Pigweed species seedlings were effectively controlled with pre- and post-emergent treatments. Selected post-emergence treatments were applied at the predetermined biologically effective dose ( $\geq 90 \%$ control of pigweed seedling) achieving excellent crop selectivity and commercially acceptable pigweed seedling control under field conditions. This study demonstrated clearly that an alternative linuronfree strategy can be developed for carrots. The novel strategy of exploring the potential to utilize the biologically effective dose of selected herbicides to achieve crop selectivity and control of pigweed seedlings was verified. 


\section{Acknowledgements}

I must begin by thanking my advisor Professor Clarence Swanton who provided a balance of guidance and trust in my abilities. Thank you to my committee members François Tardif, Darren Robinson, and Rob Nurse for providing helpful feedback during the writing process.

Thank you to Peter Smith for spending many sunsets with me in the marsh to ensure all those herbicide applications were made on time. Allison Bailey, Gerrit Schober, and Katie Trottier there is no way all the field work could have been completed without you guys! A special thanks to Shawn Janse and everyone at the Muck Crop Research Station for answering my many questions.

Michelle Edwards - statistics would have been a nightmare without your guidance. Thank you for all your help.

Thank you to the weeds group in Guelph and Ridgetown for making graduate school an unforgettable experience!

To all the ones I love, who are here or elsewhere, I would not be where I am today without you. Thank you.

Finally, I would like to thank the funding partners of this project, Fresh Vegetable Growers of Ontario, Bradford Co-operative and Growers, and Ontario Ministry of Agriculture, Food and Rural Affairs. 


\section{Table of Contents}

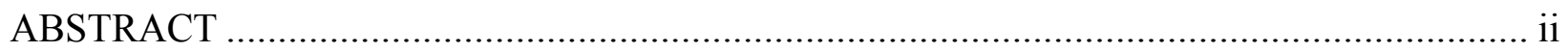

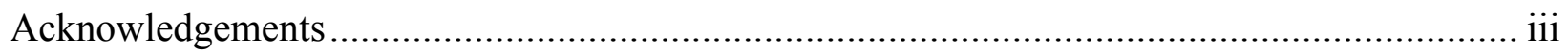

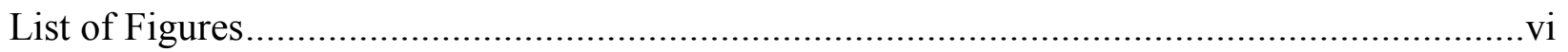

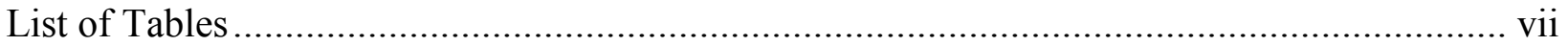

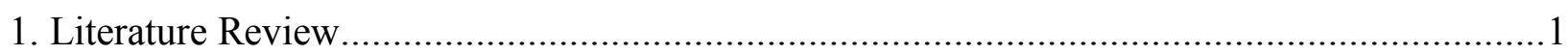

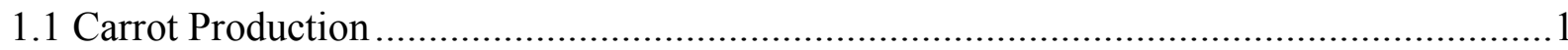

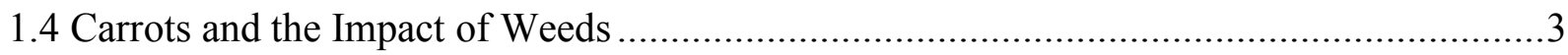

1.5 Weed Control Strategies in Carrots..............................................................................

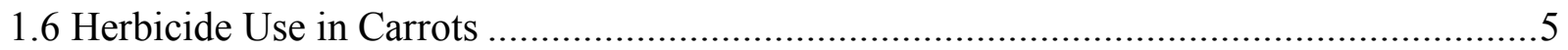

1.7 Pigweed Species in Ontario Muck Soils.......................................................................

1.8 Linuron Resistant Pigweed .....................................................................................

1.9 Looking into the Future of Weed Control in Carrots .....................................................

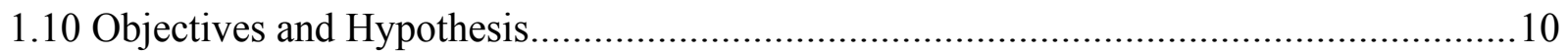

2. A Linuron-Free Weed Management Strategy for Carrot Production ......................................12

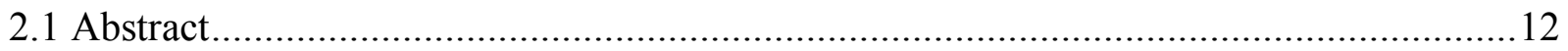

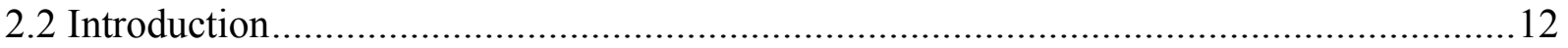

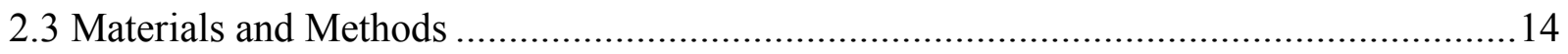

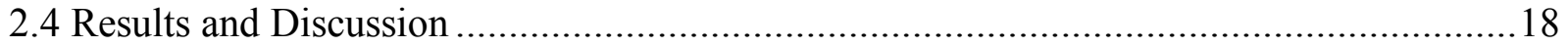

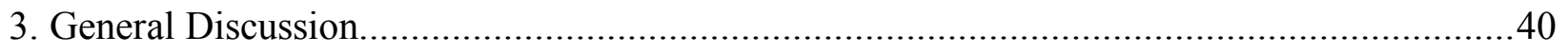

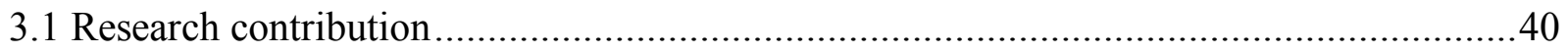


3.2 Research limitations

3.3 Future Research......

4. Literature Cited

5. Appendices 49

5.1 Tolerance of Onions to Treatments of Pethoxamid.

5.2 Tolerance of Carrots to Pethoxamid 52

5.3 Tolerance of Carrots to Pyroxasulfone .57

5.4 Optimization of Wick Weeding Technology. 61

5.5 Literature Cited 65 


\section{List of Figures}

Fig. 2. 1 Pigweed seedling emergence counts per $\mathrm{m}^{2}$ associated with growing degree days for the May 20th carrot planting in 2016 at the Muck Crop Research Station near Kettleby, Ontario, Canada. The bracket indicates the critical weed-free period of carrots (CP).

Fig. 2. 2 Pigweed seedling emergence counts from per $\mathrm{m}^{2}$ associated with growing degree days for the May $20^{\text {th }}$ carrot planting in 2016 at the Muck Crop Research Station near Kettleby, Ontario, Canada. The bracket indicates the critical weed-free period of carrots (CP).

Fig. 2. 3 Pigweed seedling emergence counts per $\mathrm{m}^{2}$ associated with the May $29^{\text {th }}$ planting of carrots in 2017 at the Muck Crop Research Station located near Kettleby, Ontario, Canada. Data collection from the quadrat continued despite the loss of the carrot trial due to heavy rainfall. The bracket indicates the critical weed-free period of carrots $(\mathrm{CP})$. 38

Fig. 2. 4 Carrot leaf dry weight per plant associated with growing degree days from samples taken from the Muck Crop Research Station near Kettleby, Ontario, Canada in 2016. The bracket

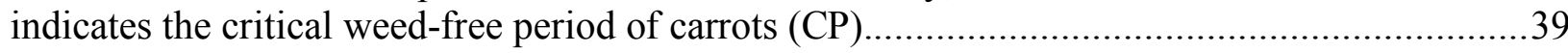

Fig. 2. 5 Carrot root dry weight per plant associated with growing degree days from samples taken from the Muck Crop Research Station near Kettleby, Ontario, Canada in 2016. The bracket indicates the critical weed-free period of carrots $(\mathrm{CP})$.

Fig. 5. 1 The wick roller that is attached to the wick weeder.

Fig. 5. 2 The wick weeder attached to a plot sprayer that was used for trials in 2016.

Fig. 5. 3 Wick Weeding with the handheld bar with the wick weeder attached.

Fig. 5. 4 Dry weed biomass for wick weeding that occurred on tall weeds at the Muck Crop Research Station located near Kettleby, Ontario, Canada in 2016.

Fig. 5. 5 Dry weed biomass for wick weeding that occurred on short weeds at the Muck Crop Research Station located near Kettleby, Ontario, Canada in 2016.

Fig. 5. 6 Dry weed biomass for wick weeding that occurred on weeds at the Muck Crop Research Station located near Kettleby, Ontario, Canada in 2017. 


\section{List of Tables}

Table 1. 1 Broadleaved herbicides available to carrot growers in Ontario. 6

Table 2. 1 Herbicide formulation, application timing, dose and manufacturer for each herbicide tested in 2016 and 2017 at the Muck Crop Research Station located near Kettleby, Ontario, Canada.

Table 2. 2 Herbicide treatment combinations for carrot field trials completed in 2016 and 2017 at the Muck Crop Research Station located near Kettleby, Ontario, Canada.

Table 2. 3 Summary of carrot planting, herbicide application, and harvest dates at the Muck Crop Research Station near Kettleby, Ontario, Canada in 2016 and 2017.

Table 2. 4 Carrot seedling emergence, pigweed species control, and yield of carrots planted May 20th, 2016 at the Muck Crop Research Station near Kettleby, Ontario, Canada..........................25

Table 2. 5 Seedling emergence, pigweed species control, and yield of carrots planted June 16th, 2016 at the Muck Crop Research Station near Kettleby, Ontario, Canada.

Table 2. 6 Seedling emergence, pigweed species control, and yield of carrots planted July 6th, 2017 at the Muck Crop Research Station near Kettleby, Ontario, Canada.

Table 5. 1 Summary of data collected for onion tolerance to pre- and post- emergence treatments of pethoxamid in 2017 at the Muck Crop Research Station located near Kettleby, Ontario, Canada.

Table 5. 2 Summary of data collected for carrot tolerance to pre- and post- emergence treatments of pethoxamid in 2016 at the Muck Crop Research Station located near Kettleby, Ontario, Canada.

Table 5. 3 Summary of data collected for carrot tolerance to pre- and post- emergence treatments of pethoxamid compared to an untreated check and standard treatments of s-metolachlor in 2017

at the Muck Crop Research Station located near Kettleby, Ontario, Canada. .55

Table 5. 4 Summary of data collected for carrot tolerance to pre- and post- emergence treatments of pyroxasulfone compared to an untreated check and standard treatment of s-metolachlor in 2016 at the Muck Crop Research Station located near Kettleby, Ontario, Canada.

Table 5. 5 Summary of data collected for carrot tolerance to pre-emergence, bunny stage, and post-emergence treatments of pyroxasulfone compared to an untreated check in 2017 at the Muck Crop Research Station located near Kettleby, Ontario, Canada. 


\section{Literature Review}

\subsection{Carrot Production}

The cultivation of carrots (Daucus carota subsp. Sativus L.) as a food crop began relatively recently. Evidence suggests carrots were initially grown as a medicinal herb as the early carrot was not palatable (Banga 1957a). The exact history of the modern day cultivated carrot is unknown, however it is known the first cultivated carrots originated from Central Asia before its introduction to Europe and later North America (Iorizzo et al. 2013; Rong et al. 2014). Cultivated carrots, which were purple and yellow at the time, first appeared in Italy at the end of the $13^{\text {th }}$ or beginning of the $14^{\text {th }}$ century (Banga 1957b). The purple carrot was an important food crop in France beginning in the $14^{\text {th }}$ century, the Netherlands in the $15^{\text {th }}$ century and Germany starting in the $18^{\text {th }}$ century (Banga $1957 b$ ). During the $18^{\text {th }}$ century the orange carrot, which was likely selected from the yellow carrot, rose in popularity with its centre of origin in the Netherlands (Banga 1957b; Iorizzo et al. 2013).

Carrots grow best in well drained, organic, peat, and sandy loam soils with a good water holding capacity and no stones (Agriculture and Agri-Food Canada 2014). Carrots grown in high organic ('muck') soil grow best with a pH of 5.5 and on sandy loam soils a pH of 6.5 (OMAFRA 2010). Carrots are planted from mid-April to June, take 120 to 180 days to mature and are subsequently harvested in July through October for fresh market carrots and October through November for processing carrots (OMAFRA 2010). The optimum germination temperature for carrots is 10 to $25^{\circ} \mathrm{C}$ and optimum growing temperature ranges from 15 to $20^{\circ} \mathrm{C}$ (Agriculture and Agri-Food Canada 2014).

In 2016, approximately 1.2 million hectares of carrots and turnips (Brassica rapa var. rapa L.) were harvested to yield 42.7 million tonnes worldwide (FAO 2017). In Canada, the farm gate 
value of carrots was 107 million dollars in 2015 with most of the production taking place in Ontario and Quebec (Agriculture and Agri-Food Canada 2015). In Ontario, 3206 hectares of carrots were harvested in 2015 with a farm gate value over 40 million dollars (Mailvaganam 2016).

Many of Ontario's carrots are grown in the Holland Marsh where the high organic soils provide optimal growing conditions. Carrots in that region are most often rotated with onions on a season to season basis, with some rotation with celery and Asian vegetables (Bartman et al. 2007). The Holland Marsh was formed in 1930 when 28 kilometers of canals were constructed, and 2833 hectares of marshland was drained for agriculture production that continues to this day (Bartram et al. 2007).

\subsection{Carrot Growth}

When a carrot first germinates, there is a clear difference between the taproot and hypocotyl (Esau 1940). As the hypocotyl and taproot grow, the distinction between the two functional parts is lost (Esau 1940). The increasing diameter of these two functional parts will rupture the cortex and the distinctive orange colour of the taproot will begin to appear (Esau 1940). Cell division is responsible for early taproot growth, while during later stages, growth is a result of cell enlargement (Esau 1940). The taproot serves as a storage organ. A study by Rosenfeld et al. (2002) showed that if favourable conditions persist, the taproot will continue to grow by thickening the roots lower parts. Therefore, under favourable conditions a carrot root would continue to slowly grow, but such conditions are a rarity and as a food crop, carrots are a biannual that is harvested annually. The taproot tip is composed of the meristematic stele, cortex, and epidermis along with a root cap (Esau 1940). After the xylem and phloem have matured, secondary vascular tissues will form along with lateral roots (Esau 1940). For more detail than 
what has been given in the preceding summary, Esau (1940) gives an excellent description of carrot root growth and development that includes excellent descriptions and figures.

Carrots are a root crop and are slow growing during the initial phases of growth making carrots especially sensitive to water availability and weed pressure. The timing and amount of rainfall along with the timing of weed emergence greatly impacts yield potential.

\subsection{The Effect of Water Availability}

A handful of studies have been completed to determine the effect of water availability on marketable yield. Carrots were found to be able to produce a marketable taproot under a wide variety of soil water conditions (White 1992). Carrots grown on high organic matter ('muck') soil with high soil moisture tended to produce lower yields when compared to carrots grown under low or medium soil moisture conditions (White 1992; Tesfaendrias et al. 2010). Specifically, high rainfall in July and more days with rain in August and September tended to reduce yield (Tesfaendrias et al. 2010). On the other hand, when drought stress was imposed on a sandy loam soil during early growth, carrot splitting increased (Sørensen et al. 1997). When drought conditions persisted three weeks prior to harvest, splitting decreased likely due to the reduction in turgor pressure (Sørensen et al. 1997). Interestingly nutritional quality is unaffected by drought (Sørensen et al. 1997).

\subsection{Carrots and the Impact of Weeds}

Weed control in carrots is important because carrots are slow to emerge and slow to produce leaves to shade the ground and are quickly outcompeted by weeds. The popularly cited review of crop sensitivity to weeds completed by Van Heemst (1985) ranked carrots as the second most sensitive crop - second only to onions. Swanton et al. (2010) found that if no weed control is

implemented, a yield loss of 92 to $100 \%$ could occur. Jensen et al. (2004) reported a yield loss 
over 50\% in the weedy checks, and Williams and Boydston (2006) reported $100 \%$ yield loss when carrots were in competition with volunteer potatoes. A volunteer potato density of $0.13 \mathrm{~m}^{-1}$ was enough to reduce carrot yield by $10 \%$ (Williams and Boydston 2006). Weed control is especially important during the critical weed-free period for carrots.

The critical weed-free period is the length of time after crop planting during which weeds must be controlled to prevent yield loss (Knezevic and Datta 2015). For carrots, the critical weed-free period ranges from 450 to 930 growing degree days (GDD) depending on planting date (Swanton et al. 2010). A later planting date (May instead of April) reduces the critical weedfree period meaning the time during which weeds must be controlled is also reduced (Swanton et al. 2010). If carrots are planted early in the season, weed control should be maintained until 450 GDD and scouting should inform weed control measures until 930 GDD (Swanton et al. 2010). These measures may include additional herbicide applications, utilization of cultural and mechanical weed control strategies if the weed population density rises to levels judged to have the potential to impact yield.

There is a wide spectrum of weeds that emerge in the Holland Marsh, however some are more problematic than others depending on the measures needed for control and the prolific nature of the species. Pigweeds (Amaranthus spp.), hairy galinsoga (Galinsoga quadriradiata Ruiz and Pav.), marsh yellow cress (Rorippa islandica (Oeder) Borb.), creeping yellow cress (Rorippa sylvestris (L.) Bess.), common groundsel (Senecio vulgaris L.), purslane (Portulaca oleracea L.), lamb's-quarters (Chenopodium album L.), chickweed (Stellaria media (L.) Vill.), oakleaf goosefoot (Chenopodium glaucum L.) and yellow nutsedge (Cyperus esculentus L.) are the main weeds that occur in that growing region. The high organic matter content of the soils in the Holland Marsh creates an environment that encourage weeds to emerge throughout the 
growing season with greater frequency than would occur in other soil types such as a sandy soil making weed control a season long endeavour.

\subsection{Weed Control Strategies in Carrots}

Options for weed control in carrots are limited due to high crop density and slow crop growth (Bell et al. 2000). Hand weeding is an important means of weed control in carrots, but cost can be prohibitive ranging from $\$ 2000$ to $2500 \mathrm{ha}^{-1}$ (Clarence Swanton, personal communication). Depending on carrot prices hand weeding can result in a net negative return (Bell et al. 2000). If a grower chooses to hand weed it is important that the weeds are removed from the field and composted to avoid the spread of seeds, especially if a species is herbicide resistant (Obeid 2017). Other methods of control include cultivation between rows, non-selective mowing of carrots grown on flat beds, and wick weeding to control weeds growing taller than the crop canopy (Obeid 2017). The creation of a false seedbed with a spring-tine harrow to promote the emergence of weeds before carrot seeding has been utilized in organic production (Peruzzi et al. 2006). Utilization of a flame-weeder to control weeds in emerged carrots has also been utilized in organic production but would not be advisable on high organic matter soil (Peruzzi et al. 2006). The most popular means of weed control in carrots is the use of herbicides.

\subsection{Herbicide Use in Carrots}

Herbicides are an important component of weed control in carrots. Unfortunately, the spectrum of broadleaved herbicides available for carrot growers in Ontario is limited (Table 1). Linuron is heavily relied upon for weed control because it is efficacious, provides excellent crop safety and is inexpensive (Bell et al. 2000). If linuron became unavailable or ineffective to growers as a method of weed control, $38 \%$ of overall weed control options would be lost 
(OMAFRA 2018). Such a prospect could become a reality due to the rise of linuron resistant pigweed.

Despite the sparse availability of herbicides for vegetables, chemical companies are not particularly interested in registering products for that segment of the market due to the cost of registering a product for a new crop and the relatively small area vegetables are grown compared to corn and soybeans. Herbicide development has become an expensive endeavour costing a company over 100 million U.S. dollars over eight years before the product reaches market (Klassen 1995; Leng 1995 in Stephenson and Solomon 2007). In addition, Canada is at a competitive disadvantage to the United States as our market is smaller, which lessens the appeal for a chemical company to register active ingredients for use in the Canadian vegetable industry (Obeid 2018). Nevertheless, herbicides will remain an important part of weed control in carrots, but it must be part of an integrated weed management system to remain sustainable.

Table 1.1 Broadleaved herbicides available to carrot growers in Ontario.

\begin{tabular}{|c|c|c|}
\hline Timing & Herbicide & Group $^{z}$ \\
\hline Pre-plant Incorporated & Trifluralin $^{\mathrm{y}}$ & 3 \\
\hline Pre-emergence & $\begin{array}{l}\text { Prometryn } \\
\text { Pendimethalin } \\
\text { Glufosinate } \\
\text { Bromoxynil }\end{array}$ & $\begin{array}{l}5 \\
3 \\
10 \\
6\end{array}$ \\
\hline Pre- or Post-emergence & $\begin{array}{l}S \text {-metolachlor } \\
\text { Linuron }\end{array}$ & $\begin{array}{l}15 \\
7\end{array}$ \\
\hline Post-emergence & Metribuzin & 5 \\
\hline Between Rows & Carfentrazone-ethyl & 14 \\
\hline
\end{tabular}




\subsection{Pigweed Species in Ontario Muck Soils}

Redroot (Amaranthus retroflexus L.) and green (Amaranthus powellii S Wats.) pigweed are native to North America (Costea et al. 2004). Redroot and green pigweed are a member of a large genus comprising of many weedy, ornamental, and food crop species. Redroot pigweed is found in all provinces of Canada except Newfoundland, while green pigweed is common to Southern Ontario (Costea et al. 2004). Like all pigweed species, green and redroot pigweed both have tap roots and ovate leaves with a notch at the tip (Cowbrough et al. 2016). The leaves of green pigweed appear hairless and shiny green, whereas redroot pigweed leaves are dull green and somewhat hairy (Cowbrough et al. 2016). On green pigweed there is a cluster of hairs present only on the upper portion of the stem and on redroot pigweed the stem has many hairs (Cowbrough et al. 2016). The seed head of green pigweed is generally long with a spikey appearance while redroot pigweed has a comparatively more compact seed head (Cowbrough et al. 2016). Pigweed is an annual species that reproduces by seed production (Weaver 2001). The seeds are very small (less than $1 \mathrm{~mm}$ ) and germinate in response to light and temperatures exceeding $15^{\circ} \mathrm{C}$ (Weaver 2001; CFIA 2018). A pigweed growing in a crop usually produces between 10000 to 30000 seeds, but it is possible for seed production to reach 100000 seeds per plant (Weaver 2001). Seeds can survive in the soil seedbank for over 40 years (Weaver 2001). Pigweed is a competitive weed species that has been shown to reduce crop yields in many studies (Costea et al. 2004).

\subsection{Linuron Resistant Pigweed}

Herbicide resistance is defined as the ability of an individual plant to survive a dose of herbicide that is lethal to the rest of the population (Cobb and Reade 2010). The plant must survive and then go on to flower and produce seed (Cobb and Reade 2010). The definition fails 
to note that the herbicide is the selective agent in the process leading to resistance. Instances of herbicide resistance date back to the 1950s, but the number of resistance cases has increased steadily since then (WSSA 2018). According to the International Survey of Herbicide Resistance, the first case of resistance to linuron in a pigweed species was in a population of redroot pigweed reported in 1984 in Bulgaria (Heap 2018). Unfortunately, no further details are presented on the case, such as the cropping system, the spread, the selection history and so forth.

The first case of a linuron resistant pigweed species reported in peer-reviewed scientific literature was that of a population of green pigweed that was discovered in Ontario (Dumont et al. 2016). Almost simultaneously, reports of common ragweed (Ambrosia artemisiifolia L.) resistant to linuron from the vegetable growing region of Québec emerged (Saint-Louis et al. 2005). Resistance cases continued to be reported and, for example, the first case of linuron resistance in redroot pigweed was discovered in Ontario in 2001 (Heap 2018).

In a survey of the major carrot growing regions in Ontario, 42 out of $47(89 \%)$ pigweed species populations tested positive for linuron resistance (Davis 2014). Linuron competes with plastoquinone to bind at the Qв site in the D1 protein of Photosystem II (PSII) complex (Dumont et al. 2016). Resistant species have a mutation in the chloroplast $p s b A$ gene which code for D1 protein which modifies the target site of linuron (Davis 2014; Dumont et al. 2016).

In the Holland Marsh specifically, 23 out of 26 populations tested positive for linuron resistance (Davis 2014). Resistance was conferred by $\mathrm{Val}_{219}$ Ile mutation for 15 redroot and one green pigweed populations, by $\mathrm{Phe}_{274} \mathrm{Val}$ for five redroot pigweed populations, and both mutations were present in two redroot pigweed populations (Davis 2014). Linuron resistant pigweed species have been found to be cross resistant to diuron and monolinuron (Dumont et al. 2016). In addition, resistant species have been found to have low level resistance to other PSII 
inhibitors such as atrazine, prometryn, metribuzin, bromoxynil and bentazon rendering these herbicides less effective (Dumont et al. 2016).

On a positive note, the resistance mutation occurs in the plastome meaning resistance cannot be passed on through pollen, but it will be spread by seed (Dumont et al. 2016). Generally, a resistant weed species will appear as an isolated patch, but over only a few years that resistant population can dominate a field and the seedbank (WSSA 2018). In a study conducted by Norsworthy et al. (2014), it was found that 20000 seeds of Palmer amaranth (Amaranthus palmeri $\mathrm{S}$ Wats.) introduced into only a $1 \mathrm{~m}^{2}$ area was able to spread throughout fields 0.53 to 0.77 ha in less two years. In this case, the spread of pigweed seed was attributed mostly to the movement of water in furrows and by tillage and harvest equipment as these activities tend to move in one direction in the field which matched the spread of the pigweed infestation (Norsworthy et al. 2014). Carrots are generally grown in beds, as such pigweed may spread in the same manner down the rows of beds by various field activities. Norsworthy et al. (2014) note that the quick spread of resistant pigweed justifies the need for a zero-tolerance weed approach when herbicides are used as part of a weed management system. After herbicide application, it was important to go back and remove escapes to prevent the spread of resistance in conjunction with other integrated weed management measures.

\subsection{Looking into the Future of Weed Control in Carrots}

The over reliance on linuron that has led to the rise of linuron resistant pigweed is not only a problem in Ontario, but other production regions - for example, linuron resistant ragweed in Québec (Simard et al. 2017). The high cost of herbicide development will limit the amount of new active ingredients that will become available, especially for low hectare vegetable crops (Fennimore et al. 2016). The limited number of herbicides available for vegetable production in 
combination with increasing herbicide resistance and hand weeding costs will hopefully spur new innovations for weed control and a return to integrated weed management. Technologies that could become mainstream means of weed control in the future are already emerging. One example is Blue River Technology's weed detection and spray system that minimizes the amount of herbicide that is applied in a field by differentiating the crop from weeds (http://www.bluerivertechnology.com). Another example is the development of JÄTI, an autonomous robot that can also differentiate between the crop and weeds, but instead uses a laser to eliminate weeds, developed by the German company SPL (http://s-p-l.at).

Until these new technologies are optimized and at a price point that makes economic sense for growers, herbicides as part of a traditional integrated weed management system will remain important. The purpose of this study was to develop a comprehensive herbicide control strategy for pigweed species seedlings. Early control is important to this strategy to keep the carrots weed free during the critical weed-free period. The strategy encompasses multiple application timings and multiple herbicides to avoid the onset of resistance. The uniqueness of this control strategy is the absence of linuron from the system.

\subsection{Objectives and Hypothesis}

\section{$\underline{\text { Objectives }}$}

1. Evaluate registered and unregistered pre-emergence treatments for weed control in carrots.

2. Evaluate the biologically effect dose of acifluorfen, oxyfluorfen, fluthiacet-methyl, and fomesafen as post-emergent treatments under field conditions. The biologically effective dose was previously determined in growth room studies. 


\section{Hypothesis}

If the dose of selected herbicides can be lowered to demonstrate crop selectivity and pigweed species seedling control, then optimum carrot yield can be achieved. 


\section{A Linuron-Free Weed Management Strategy for Carrot Production}

\subsection{Abstract}

The development of a linuron-free weed management strategy for carrot production is essential as a result of the herbicide re-evaluation programs launched by the Pest Management Regulatory Agency in Canada for herbicides registered prior to 1995 and the recent discovery of linuron resistant pigweed species in Ontario. In 2016 and 2017 field trials were conducted in one of Ontario's main carrot growing regions on high organic soils. Pigweed species seedlings were effectively controlled with pre-emergent treatments of prometryn, pendimethalin, $s$-metolachlor, or glufosinate. Post-emergent treatments of pyroxasulfone and metribuzin followed by the predetermined biologically effective dose ( $\geq 90 \%$ control of pigweed seedling) of acifluorfen, oxyfluorfen, fluthiacet-methyl, and fomesafen achieved excellent crop selectivity and commercially acceptable pigweed seedling control under field conditions. Carfentrazone-ethyl or fomesafen applied pre-emergence severely reduced emergence and in turn, yield in the wet growing season of 2017. This study demonstrated clearly that an alternative linuron-free strategy can be developed for carrots. The novel strategy of utilizing the biologically effective dose of selected herbicides to achieve crop selectivity and control of pigweed seedlings was verified.

\subsection{Introduction}

Carrots are known to be highly susceptible to weed competition. If weeds are not controlled, yield losses have been reported to range from 50 to 100\% (Jensen et al. 2004; Swanton et al. 2010). For example, Williams and Boydston (2006) found that a volunteer potato density of only $0.13 \mathrm{~m}^{-1}$ could reduce carrot yield by ten percent. The ability to manage weeds effectively in carrots has relied heavily upon the use of linuron which can be applied as a pre- or postemergence treatment (Bell et al. 2000). In Ontario, over 38\% of the registered herbicide 
treatments in carrots include linuron (OMAFRA 2018). Recently, the ability to effectively control weeds with linuron has been challenged by the ongoing government reassessment of older herbicides and by the development of resistance in pigweed species.

The Pest Management Regulatory Agency (PMRA) Re-evaluation Program was launched in 2001 to reassess 401 active ingredients registered before 1995 (Government of Canada 2009). The aim of this program was to evaluate old products with modern scientific standards to ensure the latest health and environmental criteria were met. The re-evaluations were to be carried out on all products including linuron on a 15 year cycle. Herbicides that did not meet the latest scientific standards would be discontinued.

Linuron resistance in Ontario, Canada was first reported in 1999 for green pigweed $(A$. powellii) and in 2001 for redroot pigweed (A. retroflexus) (Dumont et al. 2016; Heap 2018). In a survey of the major carrot growing regions in Ontario, 42 out of 47 (89\%) pigweed species populations tested positive for linuron resistance (Davis 2014). Linuron is known to compete with plastoquinone, binding at the $\mathrm{Q}_{\text {в }}$ site in the D1 protein of Photosystem II (PSII) complex (Dumont et al. 2016). Linuron resistant pigweed species have a target site mutation resulting from the modification of the D1 protein (Dumont et al. 2016). The most common cause of resistance was conferred by $\mathrm{Val}_{219}$ Ile mutation; the second most common mutation was conferred by $\mathrm{Phe}_{274}$ Val mutation (Davis 2014). Linuron resistant pigweed species were also found to be cross resistant to diuron and monolinuron (Dumont et al. 2016). Low level resistance to atrazine, prometryn, metribuzin, bromoxynil, and bentazon, all of which are PSII inhibitors, has also been noted (Dumont et al. 2016).

Recognizing that linuron may be discontinued as a result of the PMRA review and the likelihood that resistant pigweed species will continue to spread throughout the carrot producing 
regions of Ontario, experiments were initiated to develop a linuron-free weed management strategy. This strategy involved the testing of pre-emergence herbicides and the determination of the biologically effective dose of selected post-emergence herbicides for the control of pigweed species seedlings under field conditions. The biologically effective dose for each of the herbicides used in this study was predetermined in controlled experimental studies prior to the initiation of field studies. For this study, the hypothesis was that an optimum dose of selected herbicides could be identified that would not injure the crop and also provide control of seedlings of pigweed species, resulting in optimum yield of carrots.

\subsection{Materials and Methods}

Field trials were conducted in 2016 and 2017 at the University of Guelph Muck Crop Research Station located near Kettleby, Ontario, Canada. The muck soil contained $63 \%$ organic matter with a $\mathrm{pH}$ of 7.1. The pigweed population at the site of the research trials consisted of redroot and green pigweed, but redroot pigweed dominated the population. A distinction between the species was not made and will henceforth be referred to as pigweed species.

In 2016, two separate trials were established and seeded with carrots on May $20^{\text {th }}$ and June $16^{\text {th }}$. In 2017 , the initial planting of carrots was compromised by heavy rainfall. As a result, this trial was replanted into a newly established site on July $6^{\text {th }}$. The trial area was spring tilled initially using a disk, followed by an application of fertilizer and two passes with a cultivator. On each planting date three rows of carrots were direct seeded at a density of approximately 66 to 82 seeds per linear metre using a Stanhay precision seeder (Stanhay Webb Ltd., Bourne, UK) into raised beds spaced approximately $86 \mathrm{~cm}$ apart. Each plot consisted of two carrot beds in width by $5 \mathrm{~m}$ in length. In 2016, carrot cultivars Cellobunch and Belgrado were seeded in two separate trials whereas in 2017 only the cultivar Cellobunch was used. Fertility management and disease 
and insect control were conducted in accordance with best management practices as described in Ontario Ministry of Agriculture publications 363 Vegetable Production Recommendations and 838 Vegetable Crop Protection Guide (OMAFRA 2010; OMAFRA 2014).

Prior to the establishment of these field trials, growth room studies were conducted from 2012 to 2015 in order to determine crop selectivity and the biologically effective dose for the control of pigweed species seedlings (data not shown). The biologically effective dose was defined as the herbicide dose required to achieve greater than $90 \%$ biomass reduction of pigweed seedlings in the two to three leaf stage of development. As a result of these studies, several herbicides were selected. Information of the herbicides, including formulation, application timing, dose and manufacturer are listed in Table 2.1.

Herbicides treatments and planting, treatment application, and harvest timings for this study are listed in Table 2.2 and 2.3. All herbicide treatments were applied with a compressed air backpack sprayer with a three-tip boom calibrated to deliver $200 \mathrm{~L} \mathrm{ha}^{-1}$ at $207 \mathrm{kPa}$ through Flat Fan TeeJet XR8002 nozzles (TeeJet Technologies, Springfield, IL, USA) spaced $50 \mathrm{~cm}$ apart. The boom height was maintained at approximately $46 \mathrm{~cm}$ above the ground or crop canopy at a walking speed of approximately $3.6 \mathrm{~km} \mathrm{~h}^{-1}$ during all herbicide applications. Every replicate of each trial included a weedy and a weed-free check. The weed-free check was kept weed-free by hand-weeding. In addition to the herbicide treatments, inter-row cultivation occurred on August $17^{\text {th }}$ in 2016 and August $9^{\text {th }}$ in 2017 for each trial in order to control weeds between beds.

Carrot seedling emergence counts were recorded from a $30 \mathrm{~cm}$ length of carrot row from each of the two carrots beds and then converted to number of carrots seedlings per metre of row prior to analysis. Pigweed control ratings were recorded 14, 28, and 56 days after emergence (DAE). Weed control was visually rated as a percent of control compared to the weedy check; 
$100 \%$ indicating complete weed control and $0 \%$ indicating no control. Fifty six days after crop emergence, the surviving pigweeds were sampled manually from a $0.25 \mathrm{~m}^{2}$ section from each of the two carrot beds per plot, placed in paper bags and dried at $80^{\circ} \mathrm{C}$ until the weight remained constant. Due to the structure of the high organic matter soil, it was possible for entire pigweed plants to be pulled from the soil and the root and shoot placed in the paper bags to be dried and weighed. On October $11^{\text {th }}$ and $15^{\text {th }}$ in 2016 and on October $10^{\text {th }}$ in 2017 carrots were harvested manually (pulled from the ground and shoot removed) from $1.16 \mathrm{~m}$ from each of the two beds per plot and then combined for analysis $(\mathrm{n}=64)$. The carrots were graded into three size categories by diameter at the collar: oversized $>4.4 \mathrm{~cm}$, packaging size $2.0 \mathrm{~cm}$ to $4.4 \mathrm{~cm}$, and culls, which included carrots $<2.0 \mathrm{~cm}$ in diameter, shorter than $10 \mathrm{~cm}$, forked or split roots. Insect or disease damage on carrots was disregarded while grading. Oversized and packaging carrot weights were combined and denoted as marketable yield in $\mathrm{Mg} \mathrm{ha}^{-1}$ before statistical analysis.

Trials were established as a randomized complete block with each treatment replicated four times. Treatment analysis included the weed-free but not the untreated all season weedy check. All data was analyzed in Statistical Analysis Software (SAS Institute, Inc., Cary, NC, Version 9.4). A mixed model analysis was completed utilizing PROC GLIMMIX. Initial statistical analysis revealed a significant difference between years and location, and as a result the datum were not pooled. Variance was partitioned into fixed effects of treatment and random effect of block. Least square means estimates for each parameter were generated and compared utilizing the Tukey test $(\mathrm{P} \leq 0.05)$. A P-value was set at $\leq 0.01$ for visual pigweed control ratings. A p-value of 0.01 lowers the acceptance the results are due to chance. Visual pigweed ratings are subjective as such there was more variability in the datum. A lower p-value helps manage this variability. 
The pairwise comparisons were converted to letter codes using pdmix800.sas macro. A residual analysis was also completed to ensure error was random, homogeneous and randomly distributed. Percent visual pigweed control values were transformed into the decimal scale, where $0 \%$ was set to 0.0001 and $1 \%$ control was set to 0.9999 . A Beta distribution with a logit link function was used for visual pigweed control ratings completed at 14, 28, and 56 DAE. A lognormal distribution with an identity link function was used in the analysis of pigweed dry weight. All data was back transformed for presentation purposes. A Gaussian distribution with an identity link function was used in the analysis of carrot seedling emergence and yields.

In order to determine the seasonal growth and development pattern of carrots, separate trials were established directly behind the herbicide field trials. Carrots were planted as described above. Weeds were controlled with a standard treatment of linuron applied both pre- and postemergence according to recommendations from the Ontario Ministry of Agriculture, Food and Rural Affairs Publication 75 Guide to Weed Control (OMAFRA 2015). In 2016, ten carrots were sampled randomly from an area consisting of eight carrot beds wide by five metres in length, starting on June $15^{\text {th }}$ and continuing every week until carrots were harvested on October $15^{\text {th }}$. On each individual plant, the root and shoot were separated, cleaned and dried at $80^{\circ} \mathrm{C}$ until a consistent weight was reached. The average shoot and root weight was then plotted against growing degree days (base temperature for carrots set at $5^{\circ} \mathrm{C}$ as described in Swanton et al. 2010).

In order to determine the seasonal emergence pattern of pigweed species, a square metre of untreated soil (no herbicide applied) was established adjacent to field trials in both 2016 and 2017. Each week beginning on June $7^{\text {th }}$ in 2016 and June $14^{\text {th }}$ in 2017 , emerged pigweed seedlings were counted and recorded until September $8^{\text {th }}, 2016$ and August $21^{\text {st }}$, 2017. Pigweed 
emergence counts per square metre were then plotted against growing degree days (GDD) beginning on the date of carrot planting for each year. GDD began on May $20^{\text {th }}$ in 2016 and May $29^{\text {th }}$ in 2017 . It should be noted that the weed quadrat in 2017 was established according to the initial planting date of the carrot trial, rather than the replant because the quadrat was unaffected by the heavy rainfall whereas the trial was compromised.

\subsection{Results and Discussion}

In both 2016 and 2017, no herbicide treatment resulted in carrot foliar damage. Carrot seedling emergence, however, was affected in 2017 by pre-emergence treatments of carfentrazone-ethyl or fomesafen. This effect was different from 2016 likely due to differing weather patterns. In 2016, the growing season was hot and dry with no observed difference in emergence for any of the treatments (Table 2.4 and 2.5). This result was comparable to studies conducted on carrots by Ogbuchiekwe et al. (2004) who observed that carrots readily tolerated carfentrazone-ethyl applied as a pre-emergent treatment. In 2017, however, carrot emergence was reduced from approximately 59 seedlings $\mathrm{m}^{-1}$ (weed-free check) to counts as low as $2 \mathrm{~m}^{-1}$ for treatments including carfentrazone-ethyl or fomesafen (Table 2.6). In 2017, a heavy rainfall of approximately $36 \mathrm{~mm}$ occurred shortly after application of these two herbicides. At this time, the carrot seed coat had cracked and the primary root was growing, but the carrots had not yet emerged above the soil. Injury from carfentrazone-ethyl is known to be enhanced under conditions of high soil moisture content (Anonymous 2016; Crespo et al. 2013). Thompson and Nissen (2002) also observed that the risk of crop injury caused by carfentrazone-ethyl was increased in such crops as corn, soybeans, and wheat in a wet year compared to a dry year. A similar response to high soil moisture was also reported for fomesafen on cucumbers (Peachey et 
al. 2012). In this study, fomesafen reduced cucumber emergence and caused greater leaf injury when heavy rainfall occurred shortly after the herbicide treatment was applied.

Pigweed species were effectively controlled with selected pre- and post-emergent treatments. Treatments that included prometryn and pendimethalin or $S$-metolachlor (PRE), glufosinate (PRE/POST), pyroxasulfone and metribuzin (POST A), and lastly, acifluorfen, oxyfluorfen, with or without fluthiacet-methyl (POST B) controlled pigweed seedlings throughout the growing season while protecting yield. For example, 56 days after carrot emergence, visual control ratings of pigweed for the May $20^{\text {th }}$ and June $16^{\text {th }}$ planting dates in 2016 , ranged from 73 to $100 \%$ control when compared to the weedy check (Table 2.4 and 2.5). In 2017, these same herbicide treatments again resulted in excellent control of pigweed seedlings (Table 2.6). Control was abovr $99 \%$ for all treatments 56 DAE. Notably, the biologically effective dose of the postemergence herbicides oxyfluorfen, fluthiacet-methyl, acifluorfen, and fomesafen achieved excellent crop selectivity and commercially acceptable pigweed seedling control under field conditions.

Uncontrolled pigweed populations dramatically reduced carrot yields in 2016 and 2017. In 2016, carrot yields in the untreated check were reduced 22-fold and 80-fold compared to the weed-free check for planting dates of May $20^{\text {th }}$ and June $16^{\text {th }}$. In 2016, the average yield of the untreated check was $0.86 \mathrm{~kg} \mathrm{ha}^{-1}$ and in 2017 the average was $0.04 \mathrm{~kg} \mathrm{ha}^{-1}$. When pigweed seedlings were controlled with a combination of pre- and post-emergence herbicides, marketable carrot yields did not differ from the weed-free check. For example, in 2016 no significant differences in yield were observed for all herbicide treatments compared to the weed-free check for either planting date (Table 2.4 and 2.5). Marketable carrot yield, however, was found to be lower for treatments including carfentrazone-ethyl or fomesafen for the later planting in 2017 
(Table 2.6), as a result severely of reduced carrot seedling emergence. In addition, a treatment of bicyclopyrone also caused yields to be lower than the weed-free check. There was no increase in the proportion of culled versus marketable carrots for any of the treatments over the two years (data not shown). Yields were lower than average in 2017 as a result of the late planting date and adverse weather conditions persisting throughout the growing season.

This study demonstrated clearly that an alternative linuron-free weed management strategy for carrots can be developed. The combination of pre-emergent herbicides and notably, the role of the biologically effective dose of selected post-emergence herbicides for the control of pigweed seedlings provided options for excellent crop selectivity and carrot yields. Timing of the post-emergence treatments was critical to the success of this approach for two reasons. Firstly, the biologically effective dose determined for use in this study was effective only at the early pigweed seedling stage of growth. Secondly, pigweed seedlings emerged throughout the growing season, thus requiring repeated post-emergent treatments in order to maintain control (Figure 2.1-2.3). In 2016, pigweed emergence began to rapidly increase at 463 GDD which corresponds to June $22^{\text {nd }}$ and peaks at 691 GDD corresponding to July $7^{\text {th }}$ (Figure 2.1). Post-emergence herbicide applications were made on June $22^{\text {nd }}$, July $4^{\text {th }}$ and $11^{\text {th }}$ in order to control these emerging pigweed seedlings.

Timing of the herbicide treatments was also critical in order to keep the carrots weed-free during the critical period for weed control. Swanton et al. (2010) found that the critical weed-free period extended from 450 to $930 \mathrm{GDD}$ depending on planting date. This time period corresponded with the time of rapid leaf and root dry weight accumulation (Figure 2.4-2.5). During this time carrot root weight increased from $0.0356 \mathrm{~g}$ at $463 \mathrm{GDD}$ to $3.338 \mathrm{~g}$ per at 927 GDD. Likewise, pigweed emergence peaked during the critical weed-free period in all of the 
weed quadrats (Figure 2.1-2.3). A determining factor of yield loss is the period of time between weed and crop emergence and the weed density (Kropff 1988). As such, timely weed control was key during the critical weed-free period, especially since pigweed emergence peaked during this time, in order to optimize carrot yields.

In summary, pre-emergence treatments of prometryn, pendimethalin, $S$-metolachlor or glufosinate followed by metribuzin and pyroxasulfone applied post-emergence, were found to demonstrate excellent crop selectivity and control of pigweed seedlings when applied at the appropriate dose. Post-emergent treatments of fomesafen, acifluorfen, oxyfluorfen, and fluthiacet-methyl are herbicides not normally considered to be applicable for weed control in carrots. This novel strategy of exploring the potential of the biologically effective dose for these selected herbicides proved successful for the control of pigweed seedlings in this study. The key to success with this linuron-free weed management strategy is timing. To ensure control of pigweed seedlings, these herbicide treatments must be applied shortly after pigweed seedling emergence. In addition, carfentrazone-ethyl and fomesafen when applied prior to crop emergence, were found to result in significant reduction in carrot emergence. In conclusion, the initial hypothesis, if the dose of selected herbicides can be lowered to demonstrate crop selectivity and pigweed species seedling control, then optimum carrot yield can be achieved, was accepted. 
Table 2. 1 Herbicide formulation, application timing, dose and manufacturer for each herbicide tested in 2016 and 2017 at the Muck Crop Research Station located near Kettleby, Ontario, Canada.

\begin{tabular}{|c|c|c|c|c|c|c|}
\hline Chemical & Trade Name & Formulation & $\begin{array}{l}\text { Application } \\
\text { Timing }\end{array}$ & $\begin{array}{l}\text { Dose } \\
\text { g ai ha }^{-1}\end{array}$ & Manufacturer & Website \\
\hline Bicyclopyrone & $-{ }^{z}$ & $200 \mathrm{~g}_{\mathrm{ai}} \mathrm{L}^{-1}$ & $\mathrm{PRE}^{\mathrm{y}}$ & 50 & $\begin{array}{l}\text { Syngenta Canada Inc. } \\
\text { Guelph, ON }\end{array}$ & www.syngenta.ca \\
\hline Fomesafen & Reflex & $240 \mathrm{~g}_{\text {ai }} \mathrm{L}^{-1}$ & PRE & 240 & $\begin{array}{l}\text { Syngenta Canada Inc. } \\
\text { Guelph, ON }\end{array}$ & www.syngenta.ca \\
\hline Prometryn & Gesagard & $480 \mathrm{~g}$ ai $\mathrm{L}^{-1}$ & PRE & 3400 & $\begin{array}{l}\text { Syngenta Canada Inc. } \\
\text { Guelph, ON }\end{array}$ & www.syngenta.ca \\
\hline Pendimethalin & Prowl $\mathrm{H}_{2} \mathrm{O}$ & $455 \mathrm{~g}_{\text {ai }} \mathrm{L}^{-1}$ & PRE & 3000 & $\begin{array}{l}\text { BASF Canada Inc. } \\
\text { Mississauga, ON }\end{array}$ & www.basf.com/ca \\
\hline$S$-metolachlor & Dual II Magnum & $915 \mathrm{~g}_{\text {ai }} \mathrm{L}^{-1}$ & PRE & 1373 & $\begin{array}{l}\text { Syngenta Canada Inc. } \\
\text { Guelph, ON }\end{array}$ & www.syngenta.ca \\
\hline Carfentrazone-ethyl & Aim & $240 \mathrm{~g}_{\text {ai }} \mathrm{L}^{-1}$ & PRE/POST $^{x}$ & 28.1 & $\begin{array}{l}\text { FMC Corporation } \\
\text { Philadelphia, PA }\end{array}$ & www.fmccrop.ca \\
\hline Glufosinate & Liberty & $200 \mathrm{~g}_{\text {ai }} \mathrm{L}^{-1}$ & PRE/POST & 500 & $\begin{array}{l}\text { Bayer CropScience } \\
\text { Calgary, AB }\end{array}$ & www.cropscience.bayer.ca \\
\hline Metribuzin & Sencor & $480 \mathrm{~g}_{\text {ai }} \mathrm{L}^{-1}$ & $\operatorname{POST} \mathrm{A}^{\mathrm{w}}$ & 140 & $\begin{array}{l}\text { Bayer CropScience } \\
\text { Calgary, AB }\end{array}$ & www.cropscience.bayer.ca \\
\hline Pyroxasulfone & Zidua & $85 \mathrm{w} \mathrm{w}^{-1}$ & POST A & 89 & $\begin{array}{l}\text { BASF Corporation } \\
\text { Research Triangle Park, NC }\end{array}$ & www.basf.com \\
\hline Acifluorfen & Blazer & $240 \mathrm{~g}_{\text {ai }} \mathrm{L}^{-1}$ & POST B $^{v}$ & 18.75 & $\begin{array}{l}\text { United Phosphorus Inc. } \\
\text { King of Prussia, PA }\end{array}$ & www.uap.ca \\
\hline Fluthiacet-Methyl & Cadet & $103 \mathrm{~g}_{\text {ai }} \mathrm{L}^{-1}$ & POST B & 3.75 & $\begin{array}{l}\text { FMC Corporation } \\
\text { Philadelphia, PA }\end{array}$ & www.fmc.com \\
\hline Fomesafen & Reflex & $240 \mathrm{~g}_{\text {ai }} \mathrm{L}^{-1}$ & POST B & 10 & $\begin{array}{l}\text { Syngenta Canada Inc. } \\
\text { Guelph, ON }\end{array}$ & www.syngenta.ca \\
\hline Oxyfluorfen & Goal & $240 \mathrm{~g}_{\text {ai }} \mathrm{L}^{-1}$ & POST B & 60 & $\begin{array}{l}\text { Dow AgroSciences Canada Inc. } \\
\text { Calgary, AB }\end{array}$ & www.dowagro.com \\
\hline
\end{tabular}

\footnotetext{
${ }^{\mathrm{z}}$ The dashed lines (--) indicate no trade name available.

${ }^{y}$ Pre-emergent applied just after planting (PRE).

${ }^{\mathrm{x}}$ Pre-/Post- emergent applied prior to carrot emergence, but after weeds had emerged (PRE/POST).

${ }^{\mathrm{w}}$ Post-emergent applied at the two to three leaf stage of the carrots (POST A).

${ }^{\mathrm{v}}$ Post-emergent (as required), applied as new weeds emerge, for example, after a rainfall event giving rise to a flush of newly emerged weeds (POST B).
} 
Table 2. 2 Herbicide treatment combinations for carrot field trials completed in 2016 and 2017 at the Muck Crop Research Station located near Kettleby, Ontario, Canada.

\begin{tabular}{|c|c|c|c|}
\hline $\mathrm{PRE}^{\mathrm{Z}}$ & PRE/POST $^{\mathrm{y}}$ & POST A $^{\mathrm{x}}$ & POST B $^{w}$ \\
\hline \multicolumn{4}{|l|}{ Weedy Check } \\
\hline \multicolumn{4}{|c|}{ Weed-Free Check } \\
\hline $\begin{array}{l}\text { Prometryn } \\
\text { Pendimethalin }\end{array}$ & Glufosinate & $\begin{array}{l}\text { Pyroxasulfone } \\
\text { Metribuzin }\end{array}$ & $\begin{array}{l}\text { Acifluorfen } \\
\text { Oxyfluorfen }\end{array}$ \\
\hline $\begin{array}{l}\text { Prometryn } \\
S \text {-metolachlor }\end{array}$ & Glufosinate & $\begin{array}{l}\text { Pyroxasulfone } \\
\text { Metribuzin }\end{array}$ & $\begin{array}{l}\text { Acifluorfen } \\
\text { Oxyfluorfen }\end{array}$ \\
\hline $\begin{array}{l}\text { Prometryn } \\
\text { Fomesafen }\end{array}$ & Glufosinate & $\begin{array}{l}\text { Pyroxasulfone } \\
\text { Metribuzin }\end{array}$ & $\begin{array}{l}\text { Acifluorfen } \\
\text { Oxyfluorfen }\end{array}$ \\
\hline $\begin{array}{l}\text { Prometryn } \\
S \text {-metolachlor } \\
\text { Fomesafen }\end{array}$ & Glufosinate & $\begin{array}{l}\text { Pyroxasulfone } \\
\text { Metribuzin }\end{array}$ & $\begin{array}{l}\text { Acifluorfen } \\
\text { Oxyfluorfen }\end{array}$ \\
\hline $\begin{array}{l}\text { Prometryn } \\
\text { Pendimethalin }\end{array}$ & Carfentrazone-ethyl & $\begin{array}{l}\text { Pyroxasulfone } \\
\text { Metribuzin }\end{array}$ & $\begin{array}{l}\text { Acifluorfen } \\
\text { Oxyfluorfen }\end{array}$ \\
\hline $\begin{array}{l}\text { Prometryn } \\
S \text {-metolachlor }\end{array}$ & Carfentrazone-ethyl & $\begin{array}{l}\text { Pyroxasulfone } \\
\text { Metribuzin }\end{array}$ & $\begin{array}{l}\text { Acifluorfen } \\
\text { Oxyfluorfen }\end{array}$ \\
\hline $\begin{array}{l}\text { Prometryn } \\
\text { Fomesafen }\end{array}$ & Carfentrazone-ethyl & $\begin{array}{l}\text { Pyroxasulfone } \\
\text { Metribuzin }\end{array}$ & $\begin{array}{l}\text { Acifluorfen } \\
\text { Oxyfluorfen }\end{array}$ \\
\hline $\begin{array}{l}\text { Prometryn } \\
S \text {-metolachlor } \\
\text { Fomesafen }\end{array}$ & Carfentrazone-ethyl & $\begin{array}{l}\text { Pyroxasulfone } \\
\text { Metribuzin }\end{array}$ & $\begin{array}{l}\text { Acifluorfen } \\
\text { Oxyfluorfen }\end{array}$ \\
\hline $\begin{array}{l}\text { Prometryn } \\
S \text {-metolachlor }\end{array}$ & Glufosinate & $\begin{array}{l}\text { Pyroxasulfone } \\
\text { Metribuzin }\end{array}$ & $\begin{array}{l}\text { Fomesafen } \\
\text { Oxyfluorfen }\end{array}$ \\
\hline $\begin{array}{l}\text { Prometryn } \\
S \text {-metolachlor }\end{array}$ & Glufosinate & $\begin{array}{l}\text { Pyroxasulfone } \\
\text { Metribuzin }\end{array}$ & $\begin{array}{l}\text { Fluthiacet-methyl } \\
\text { Oxyfluorfen }\end{array}$ \\
\hline $\begin{array}{l}\text { Prometryn } \\
S \text {-metolachlor }\end{array}$ & Glufosinate & $\begin{array}{l}\text { Pyroxasulfone } \\
\text { Metribuzin }\end{array}$ & $\begin{array}{l}\text { Acifluorfen } \\
\text { Oxyfluorfen } \\
\text { Fomesafen }\end{array}$ \\
\hline $\begin{array}{l}\text { Prometryn } \\
S \text {-metolachlor }\end{array}$ & Glufosinate & $\begin{array}{l}\text { Pyroxasulfone } \\
\text { Metribuzin }\end{array}$ & $\begin{array}{l}\text { Acifluorfen } \\
\text { Oxyfluorfen } \\
\text { Fluthiacet-methyl }\end{array}$ \\
\hline Bicyclopyrone & Glufosinate & $\begin{array}{l}\text { Pyroxasulfone } \\
\text { Metribuzin }\end{array}$ & $\begin{array}{l}\text { Acifluorfen } \\
\text { Oxyfluorfen } \\
\text { Fluthiacet-methyl }\end{array}$ \\
\hline $\begin{array}{l}\text { Bicyclopyrone } \\
S \text {-metolachlor }\end{array}$ & Glufosinate & $\begin{array}{l}\text { Pyroxasulfone } \\
\text { Metribuzin }\end{array}$ & $\begin{array}{l}\text { Acifluorfen } \\
\text { Oxyfluorfen } \\
\text { Fluthiacet-methyl }\end{array}$ \\
\hline
\end{tabular}

${ }^{\mathrm{z}}$ Pre-emergent applied just after planting (PRE).

${ }^{y}$ Pre-/Post- emergent applied prior to carrot emergence, but after weeds had emerged (PRE/POST).

${ }^{x}$ Post-emergent applied at the two to three leaf stage of the carrots (POST A).

${ }^{\mathrm{w}}$ Post-emergent (as required), applied as new weeds emerge, for example, after a rainfall event giving rise to a flush of newly emerged weeds (POST B). 
Table 2.3 Summary of carrot planting, herbicide application, and harvest dates at the Muck Crop Research Station near Kettleby, Ontario, Canada in 2016 and 2017.

\begin{tabular}{llllllll}
\hline Year & Planting & PRE $^{\mathrm{z}}$ & PRE/POST $^{\mathrm{y}}$ & POST A $^{\mathrm{x}}$ & POST B $^{\mathrm{w}}$ & POST B & Harvest \\
\hline 2016 & 20 May & 25 May & -- $^{\mathrm{v}}$ & 22 June & 4 July & 11 July & 15 October \\
2016 & 16 June & 16 June & 19 June & 16 July & 20 July & 2 August & 11 October \\
2017 & 6 July & 6 July & 11 July & 1 August & 21 August & -- & 10 October \\
\hline
\end{tabular}

${ }^{\mathrm{z}}$ Pre-emergent applied just after planting (PRE).

${ }^{y}$ Pre-/Post- emergent applied prior to carrot emergence, but after weeds had emerged (PRE/POST).

${ }^{x}$ Post-emergent applied at the two to three leaf stage of the carrots (POST A).

${ }^{\mathrm{w}}$ Post-emergent (as required), applied as new weeds emerge, for example, after a rainfall event giving rise to a flush of newly emerged weeds (POST B).

${ }^{\mathrm{v}}$ The dashed lines (--) indicate a spray that was not completed. In 2016, the carrots emerged quicker than expected therefore the spray was not completed. In 2017, a second POST B application was not necessary. 
Table 2. 4 Carrot seedling emergence, pigweed species control, and yield of carrots planted May 20th, 2016 at the Muck Crop Research Station near Kettleby, Ontario, Canada.

\begin{tabular}{|c|c|c|c|c|c|c|c|}
\hline \multirow{2}{*}{\multicolumn{2}{|c|}{ Treatment }} & \multirow{3}{*}{$\begin{array}{c}\begin{array}{c}\text { Emergence } \\
\text { carrot } \mathrm{m}^{-1} \text { row }^{\mathrm{z}}\end{array} \\
50 \mathrm{abc}\end{array}$} & \multicolumn{3}{|c|}{ Visual Pigweed Control Ratings ${ }^{y}$} & \multirow{3}{*}{ 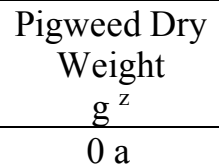 } & \multirow{3}{*}{$\begin{array}{c}\begin{array}{c}\text { Yield } \\
\mathrm{Mg} \mathrm{ha}^{-1}\end{array} \\
50 \mathrm{abc}\end{array}$} \\
\hline & & & \multirow{2}{*}{$\frac{14 \mathrm{DAE}^{\mathrm{x}}}{100 \mathrm{a}}$} & \multirow{2}{*}{$\begin{array}{c}28 \mathrm{DAE} \\
100\end{array}$} & \multirow{2}{*}{$\begin{array}{r}56 \mathrm{DAE} \\
100 \mathrm{a} \\
\end{array}$} & & \\
\hline Weed-free check & -- & & & & & & \\
\hline Prometryn & $\mathrm{PRE}^{\mathrm{w}}$ & & & & & & \\
\hline Pendimethalin & PRE & & & & & & \\
\hline Glufosinate & PRE/POST ${ }^{v}$ & & & & & & \\
\hline Pyroxasulfone & POST A ${ }^{u}$ & $51 \mathrm{ab}$ & $90 \mathrm{a}$ & $88 \mathrm{a}$ & $73 \mathrm{a}$ & $0.72 \mathrm{a}$ & $55 \mathrm{ab}$ \\
\hline Metribuzin & POST A & & & & & & \\
\hline Acifluorfen & POST B ${ }^{t}$ & & & & & & \\
\hline Oxyfluorfen & POST B & & & & & & \\
\hline Prometryn & PRE & & & & & & \\
\hline$S$-Metolachlor & PRE & & & & & & \\
\hline Glufosinate & PRE/POST & & & & & & \\
\hline Pyroxasulfone & POST A & $50 \mathrm{abc}$ & $100 \mathrm{a}$ & $100 \mathrm{a}$ & $100 \mathrm{a}$ & $0 \mathrm{a}$ & $60 \mathrm{a}$ \\
\hline Metribuzin & POST A & & & & & & \\
\hline Acifluorfen & POST B & & & & & & \\
\hline Oxyfluorfen & POST B & & & & & & \\
\hline Prometryn & PRE & & & & & & \\
\hline Fomesafen & PRE & & & & & & \\
\hline Glufosinate & PRE/POST & & & & & & \\
\hline Pyroxasulfone & POST A & $34 \mathrm{bc}$ & $75 \mathrm{a}$ & $85 \mathrm{a}$ & $78 \mathrm{a}$ & $2.37 \mathrm{a}$ & $44 \mathrm{abc}$ \\
\hline Metribuzin & POST A & & & & & & \\
\hline Acifluorfen & POST B & & & & & & \\
\hline Oxyfluorfen & POST B & & & & & & \\
\hline Prometryn & PRE & & & & & & \\
\hline$S$-metolachlor & PRE & & & & & & \\
\hline Fomesafen & PRE & & & & & & \\
\hline Glufosinate & $\mathrm{PRE} / \mathrm{POST}$ & (4) ahc & 87 & 91 a & 90 & a 002 & $40 \mathrm{bc}$ \\
\hline Pyroxasulfone & POST A & $42 \mathrm{abc}$ & $0 / \mathrm{d}$ & $91 \mathrm{~d}$ & $90 \mathrm{~d}$ & $0.02 \mathrm{~d}$ & $400 \mathrm{c}$ \\
\hline Metribuzin & POST A & & & & & & \\
\hline Acifluorfen & POST B & & & & & & \\
\hline Oxyfluorfen & POST B & & & & & & \\
\hline
\end{tabular}




\begin{tabular}{|c|c|c|c|c|c|c|c|}
\hline \multirow{2}{*}{\multicolumn{2}{|c|}{ Treatment }} & \multirow{2}{*}{$\begin{array}{c}\text { Emergence } \\
\text { carrot } \mathrm{m}^{-1} \text { row }^{\mathrm{z}}\end{array}$} & \multicolumn{3}{|c|}{ Visual Pigweed Control Ratings ${ }^{y}$} & \multirow{2}{*}{$\begin{array}{c}\text { Pigweed Dry } \\
\text { Weight } \\
\mathrm{g}^{\mathrm{z}} \\
\end{array}$} & \multirow{2}{*}{$\begin{array}{c}\text { Yield } \\
\mathrm{Mg} \mathrm{ha}^{-1} \mathrm{z}\end{array}$} \\
\hline & & & $14 \mathrm{DAE}^{\mathrm{x}}$ & $28 \mathrm{DAE}$ & $56 \mathrm{DAE}$ & & \\
\hline Prometryn & PRE & \multirow{7}{*}{$57 \mathrm{a}$} & \multirow{7}{*}{$77 \mathrm{a}$} & \multirow{7}{*}{$90 \mathrm{a}$} & \multirow{7}{*}{$83 \mathrm{a}$} & \multirow{7}{*}{$0.10 \mathrm{a}$} & \multirow{7}{*}{$52 \mathrm{abc}$} \\
\hline Pendimethalin & PRE & & & & & & \\
\hline Carfentrazone-ethyl & PRE/POST & & & & & & \\
\hline Pyroxasulfone & POST A & & & & & & \\
\hline Metribuzin & POST A & & & & & & \\
\hline Acifluorfen & POST B & & & & & & \\
\hline Oxyfluorfen & POST B & & & & & & \\
\hline Prometryn & PRE & \multirow{7}{*}{$52 \mathrm{ab}$} & \multirow{7}{*}{$98 \mathrm{a}$} & \multirow{7}{*}{$99 \mathrm{a}$} & \multirow{7}{*}{$100 \mathrm{a}$} & \multirow{7}{*}{$0.00 \mathrm{a}$} & \multirow{7}{*}{$51 \mathrm{abc}$} \\
\hline$S$-metolachlor & PRE & & & & & & \\
\hline Carfentrazone-ethyl & PRE/POST & & & & & & \\
\hline Pyroxasulfone & POST A & & & & & & \\
\hline Metribuzin & POST A & & & & & & \\
\hline Acifluorfen & POST B & & & & & & \\
\hline Oxyfluorfen & POST B & & & & & & \\
\hline Prometryn & PRE & \multirow{7}{*}{$43 \mathrm{abc}$} & \multirow{7}{*}{$65 \mathrm{a}$} & \multirow{7}{*}{$76 \mathrm{a}$} & \multirow{7}{*}{$60 \mathrm{a}$} & \multirow{7}{*}{$2.31 \mathrm{a}$} & \multirow{7}{*}{$34 \mathrm{c}$} \\
\hline Fomesafen & PRE & & & & & & \\
\hline Carfentrazone-ethyl & PRE/POST & & & & & & \\
\hline Pyroxasulfone & POST A & & & & & & \\
\hline Metribuzin & POST A & & & & & & \\
\hline Acifluorfen & POST B & & & & & & \\
\hline Oxyfluorfen & POST B & & & & & & \\
\hline Prometryn & PRE & \multirow{8}{*}{$28 \mathrm{c}$} & \multirow{8}{*}{$94 \mathrm{a}$} & \multirow{8}{*}{$92 \mathrm{a}$} & \multirow{8}{*}{$86 \mathrm{a}$} & \multirow{8}{*}{$0 \mathrm{a}$} & \multirow{8}{*}{$37 \mathrm{bc}$} \\
\hline$S$-metolachlor & PRE & & & & & & \\
\hline Fomesafen & PRE & & & & & & \\
\hline Carfentrazone-ethyl & PRE/POST & & & & & & \\
\hline Pyroxasulfone & POST A & & & & & & \\
\hline Metribuzin & POST A & & & & & & \\
\hline Acifluorfen & POST B & & & & & & \\
\hline Oxyfluorfen & POST B & & & & & & \\
\hline
\end{tabular}




\begin{tabular}{|c|c|c|c|c|c|c|c|}
\hline \multirow{2}{*}{\multicolumn{2}{|c|}{ Treatment }} & \multirow{2}{*}{$\begin{array}{c}\text { Emergence } \\
\text { carrot } \mathrm{m}^{-1} \text { row }^{\mathrm{z}}\end{array}$} & \multicolumn{3}{|c|}{ Visual Pigweed Control Ratings ${ }^{\mathrm{y}}$} & \multirow{2}{*}{$\begin{array}{c}\text { Pigweed Dry } \\
\text { Weight } \\
\mathrm{g}^{\mathrm{z}} \\
\end{array}$} & \multirow{2}{*}{$\begin{array}{c}\text { Yield } \\
\text { Mg ha }^{-1 \text { z }}\end{array}$} \\
\hline & & & $14 \mathrm{DAE}^{\mathrm{x}}$ & $28 \mathrm{DAE}$ & $56 \mathrm{DAE}$ & & \\
\hline Prometryn & PRE & \multirow{7}{*}{$57 \mathrm{a}$} & \multirow{7}{*}{$94 \mathrm{a}$} & \multirow{7}{*}{$98 \mathrm{a}$} & \multirow{7}{*}{$97 \mathrm{a}$} & \multirow{7}{*}{$0 \mathrm{a}$} & \multirow{7}{*}{$49 \mathrm{abc}$} \\
\hline$S$-metolachlor & PRE & & & & & & \\
\hline Glufosinate & PRE/POST & & & & & & \\
\hline Pyroxasulfone & POST A & & & & & & \\
\hline Metribuzin & POST A & & & & & & \\
\hline Fomesafen & POST B & & & & & & \\
\hline Oxyfluorfen & POST B & & & & & & \\
\hline Prometryn & PRE & \multirow{7}{*}{$52 \mathrm{ab}$} & \multirow{7}{*}{$90 \mathrm{a}$} & \multirow{7}{*}{$92 \mathrm{a}$} & \multirow{7}{*}{$91 \mathrm{a}$} & \multirow{7}{*}{$0.07 \mathrm{a}$} & \multirow{7}{*}{$45 \mathrm{abc}$} \\
\hline$S$-metolachlor & PRE & & & & & & \\
\hline Glufosinate & PRE/POST & & & & & & \\
\hline Pyroxasulfone & POST A & & & & & & \\
\hline Metribuzin & POST A & & & & & & \\
\hline Fluthiacet-methyl & POST B & & & & & & \\
\hline Oxyfluorfen & POST B & & & & & & \\
\hline Prometryn & PRE & \multirow{8}{*}{$54 \mathrm{ab}$} & \multirow{8}{*}{$75 \mathrm{a}$} & \multirow{8}{*}{$82 \mathrm{a}$} & \multirow{8}{*}{$71 \mathrm{a}$} & \multirow{8}{*}{$1.62 \mathrm{a}$} & \multirow{8}{*}{$51 \mathrm{abc}$} \\
\hline$S$-metolachlor & PRE & & & & & & \\
\hline Glufosinate & PRE/POST & & & & & & \\
\hline Pyroxasulfone & POST A & & & & & & \\
\hline Metribuzin & POST A & & & & & & \\
\hline Fomesafen & POST B & & & & & & \\
\hline Acifluorfen & POST B & & & & & & \\
\hline Oxyfluorfen & POST B & & & & & & \\
\hline Prometryn & PRE & \multirow{8}{*}{$49 \mathrm{abc}$} & \multirow{8}{*}{$97 \mathrm{a}$} & \multirow{8}{*}{$98 \mathrm{a}$} & \multirow{8}{*}{$95 \mathrm{a}$} & \multirow{8}{*}{$0 \mathrm{a}$} & \multirow{8}{*}{$56 \mathrm{ab}$} \\
\hline$S$-metolachlor & PRE & & & & & & \\
\hline Glufosinate & PRE/POST & & & & & & \\
\hline Pyroxasulfone & POST A & & & & & & \\
\hline Metribuzin & POST A & & & & & & \\
\hline Fluthiacet-methyl & POST B & & & & & & \\
\hline Acifluorfen & POST B & & & & & & \\
\hline Oxyfluorfen & POST B & & & & & & \\
\hline
\end{tabular}




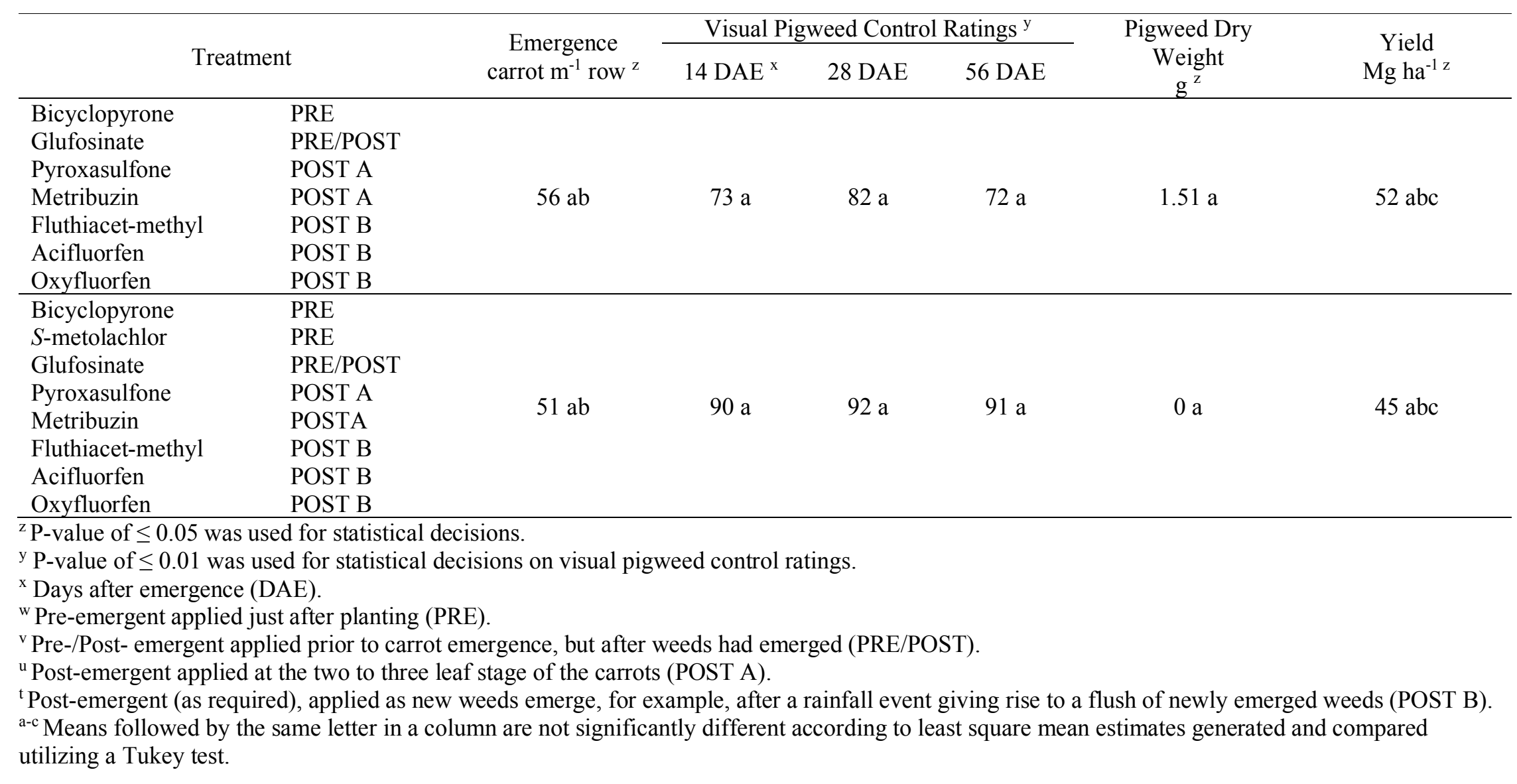


Table 2. 5 Seedling emergence, pigweed species control, and yield of carrots planted June 16th, 2016 at the Muck Crop Research Station near Kettleby, Ontario, Canada.

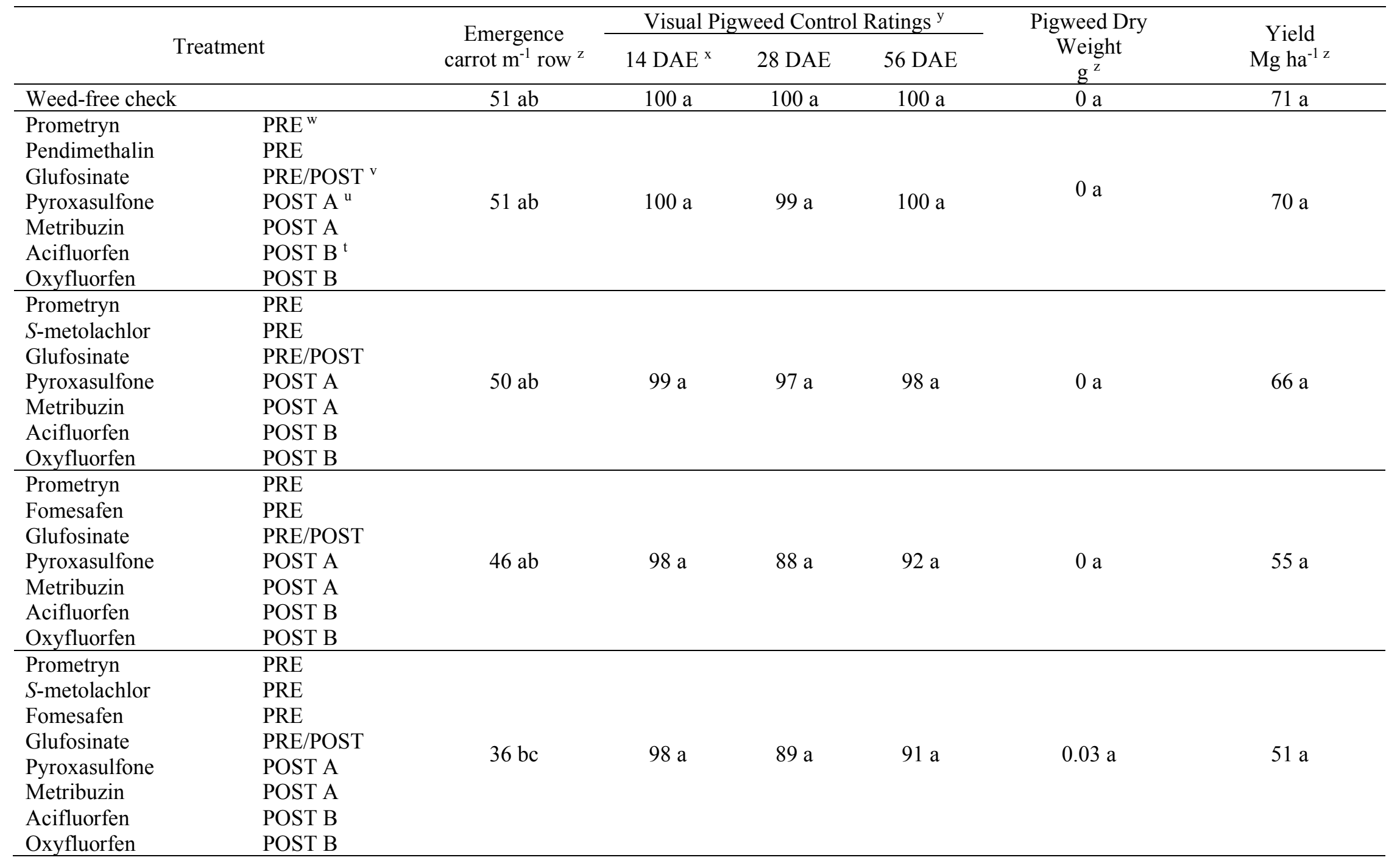




\begin{tabular}{|c|c|c|c|c|c|c|c|}
\hline \multirow{2}{*}{\multicolumn{2}{|c|}{ Treatment }} & \multirow{2}{*}{$\begin{array}{c}\text { Emergence } \\
\text { carrot } \mathrm{m}^{-1} \text { row }^{\mathrm{z}}\end{array}$} & \multicolumn{3}{|c|}{ Visual Pigweed Control Ratings ${ }^{\mathrm{y}}$} & \multirow{2}{*}{$\begin{array}{c}\text { Pigweed Dry } \\
\text { Weight } \\
\mathrm{g}^{\mathrm{z}} \\
\end{array}$} & \multirow{2}{*}{$\begin{array}{c}\text { Yield } \\
\mathrm{Mg} \mathrm{ha}^{-1} \mathrm{z}\end{array}$} \\
\hline & & & $14 \mathrm{DAE}^{\mathrm{x}}$ & $28 \mathrm{DAE}$ & $56 \mathrm{DAE}$ & & \\
\hline Prometryn & PRE & \multirow{7}{*}{$48 \mathrm{ab}$} & \multirow{7}{*}{$96 \mathrm{a}$} & \multirow{7}{*}{$87 \mathrm{a}$} & \multirow{7}{*}{$83 \mathrm{a}$} & \multirow{7}{*}{$0.05 \mathrm{a}$} & \multirow{7}{*}{$62 \mathrm{a}$} \\
\hline Pendimethalin & PRE & & & & & & \\
\hline Carfentrazone-ethyl & PRE/POST & & & & & & \\
\hline Pyroxasulfone & POST A & & & & & & \\
\hline Metribuzin & POST A & & & & & & \\
\hline Acifluorfen & POST B & & & & & & \\
\hline Oxyfluorfen & POST B & & & & & & \\
\hline Prometryn & PRE & \multirow{7}{*}{$46 \mathrm{ab}$} & \multirow{7}{*}{$83 \mathrm{a}$} & \multirow{7}{*}{$75 \mathrm{a}$} & \multirow{7}{*}{$84 \mathrm{a}$} & \multirow{7}{*}{$0.01 \mathrm{a}$} & \multirow{7}{*}{$46 \mathrm{a}$} \\
\hline$S$-metolachlor & PRE & & & & & & \\
\hline Carfentrazone-ethyl & PRE/POST & & & & & & \\
\hline Pyroxasulfone & POST A & & & & & & \\
\hline Metribuzin & POST A & & & & & & \\
\hline Acifluorfen & POST B & & & & & & \\
\hline Oxyfluorfen & POST B & & & & & & \\
\hline Prometryn & PRE & \multirow{7}{*}{$46 \mathrm{ab}$} & \multirow{7}{*}{$100 \mathrm{a}$} & \multirow{7}{*}{$99 \mathrm{a}$} & \multirow{7}{*}{$98 \mathrm{a}$} & \multirow{7}{*}{$0 \mathrm{a}$} & \multirow{7}{*}{$61 \mathrm{a}$} \\
\hline Fomesafen & PRE & & & & & & \\
\hline Carfentrazone-ethyl & PRE/POST & & & & & & \\
\hline Pyroxasulfone & POST A & & & & & & \\
\hline Metribuzin & POST A & & & & & & \\
\hline Acifluorfen & POST B & & & & & & \\
\hline Oxyfluorfen & POST B & & & & & & \\
\hline Prometryn & PRE & \multirow{8}{*}{$26 \mathrm{c}$} & \multirow{8}{*}{$99 \mathrm{a}$} & \multirow{8}{*}{$96 \mathrm{a}$} & \multirow{8}{*}{$97 \mathrm{a}$} & \multirow{8}{*}{$0 \mathrm{a}$} & \multirow{8}{*}{$48 \mathrm{a}$} \\
\hline$S$-metolachlor & PRE & & & & & & \\
\hline Fomesafen & PRE & & & & & & \\
\hline Carfentrazone-ethyl & PRE/POST & & & & & & \\
\hline Pyroxasulfone & POST A & & & & & & \\
\hline Metribuzin & POST A & & & & & & \\
\hline Acifluorfen & POST B & & & & & & \\
\hline Oxyfluorfen & POST B & & & & & & \\
\hline
\end{tabular}




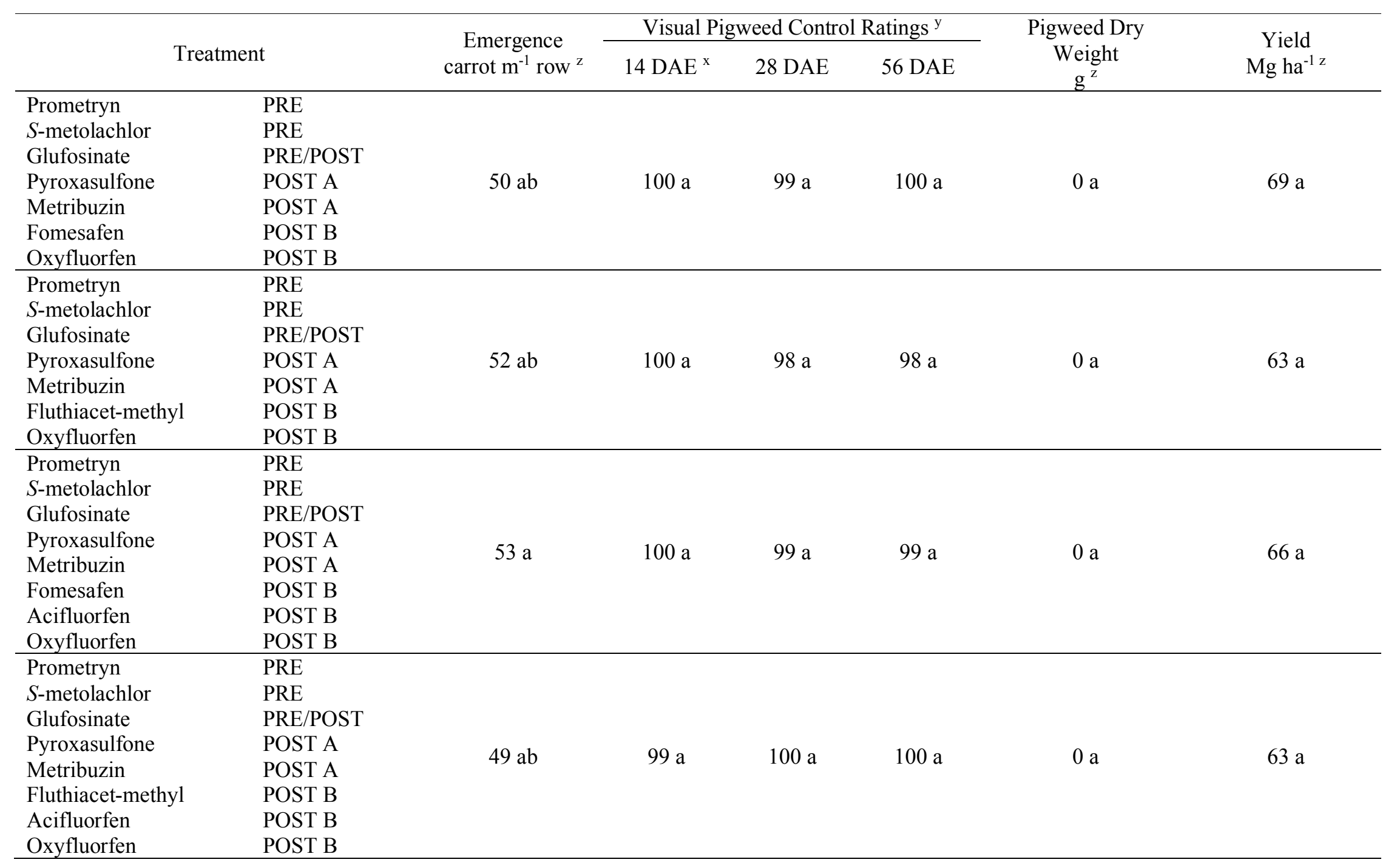




\begin{tabular}{|c|c|c|c|c|c|c|c|}
\hline \multirow{2}{*}{\multicolumn{2}{|c|}{ Treatment }} & \multirow{2}{*}{$\begin{array}{l}\text { Emergence } \\
\text { carrot } \mathrm{m}^{-1} \text { row }\end{array}$} & \multicolumn{3}{|c|}{ Visual Pigweed Control Ratings $^{\mathrm{y}}$} & \multirow{2}{*}{$\begin{array}{l}\text { Pigweed Dry } \\
\text { Weight } \\
\mathrm{g}^{\mathrm{z}}\end{array}$} & \multirow{2}{*}{$\begin{array}{l}\text { Yield } \\
\text { Mg ha }^{-1 \text { z }}\end{array}$} \\
\hline & & & $14 \mathrm{DAE}^{\mathrm{x}}$ & $28 \mathrm{DAE}$ & $56 \mathrm{DAE}$ & & \\
\hline Bicyclopyrone & PRE & \multirow{7}{*}{$52 \mathrm{ab}$} & \multirow{7}{*}{$88 \mathrm{a}$} & \multirow{7}{*}{$84 \mathrm{a}$} & \multirow{7}{*}{$86 \mathrm{a}$} & \multirow{7}{*}{$0 \mathrm{a}$} & \multirow{7}{*}{$58 \mathrm{a}$} \\
\hline Glufosinate & PRE/POST & & & & & & \\
\hline Pyroxasulfone & POST A & & & & & & \\
\hline Metribuzin & POST A & & & & & & \\
\hline Fluthiacet-methyl & POST B & & & & & & \\
\hline Acifluorfen & POST B & & & & & & \\
\hline Oxyfluorfen & POST B & & & & & & \\
\hline Bicyclopyrone & PRE & \multirow{8}{*}{$45 \mathrm{ab}$} & \multirow{8}{*}{94 a } & \multirow{8}{*}{$87 \mathrm{a}$} & \multirow{8}{*}{$95 \mathrm{a}$} & \multirow{8}{*}{$0 \mathrm{a}$} & \multirow{8}{*}{$51 \mathrm{a}$} \\
\hline$S$-metolachlor & PRE & & & & & & \\
\hline Glufosinate & $\mathrm{PRE} / \mathrm{POST}$ & & & & & & \\
\hline Pyroxasulfone & POST A & & & & & & \\
\hline Metribuzin & POSTA & & & & & & \\
\hline Fluthiacet-methyl & POST B & & & & & & \\
\hline Acifluorfen & POST B & & & & & & \\
\hline Oxyfluorfen & POST B & & & & & & \\
\hline \multicolumn{8}{|c|}{${ }^{\mathrm{z}} \mathrm{P}$-value of $\leq 0.05$ was used for statistical decisions. } \\
\hline \multicolumn{8}{|c|}{${ }^{\mathrm{y}} \mathrm{P}$-value of $\leq 0.01$ was used for statistical decisions on visual pigweed control ratings. } \\
\hline \multicolumn{8}{|c|}{ x Days after emergence (DAE). } \\
\hline \multicolumn{8}{|c|}{${ }^{\mathrm{w}}$ Pre-emergent applied just after planting (PRE). } \\
\hline \multicolumn{8}{|c|}{${ }^{\mathrm{v}}$ Pre-/Post- emergent applied prior to carrot emergence, but after weeds had emerged (PRE/POST). } \\
\hline \multicolumn{8}{|c|}{ u Post-emergent applied at the two to three leaf stage of the carrots (POST A). } \\
\hline \multicolumn{8}{|c|}{$\begin{array}{l}{ }^{\mathrm{t}} \text { Post-emergent (as required), applied as new weeds emerge, for example, after a rainfall event giving rise to a flush of newly emerged weeds (POST B) } \\
\mathrm{a-c} \text { Means followed by the same letter in a column are not significantly different according to least square mean estimates generated and compared } \\
\text { utilizing a Tukey test. }\end{array}$} \\
\hline
\end{tabular}


Table 2. 6 Seedling emergence, pigweed species control, and yield of carrots planted July 6th, 2017 at the Muck Crop Research Station near Kettleby, Ontario, Canada.

\begin{tabular}{|c|c|c|c|c|c|c|c|}
\hline \multirow{2}{*}{\multicolumn{2}{|c|}{ Treatment }} & \multirow{2}{*}{$\begin{array}{l}\text { Emergence } \\
{\text { carrot } \mathrm{m}^{-1} \text { row }}^{\mathrm{z}}\end{array}$} & \multicolumn{3}{|c|}{ Visual Pigweed Control Ratings ${ }^{\mathrm{y}}$} & \multirow{2}{*}{$\begin{array}{c}\text { Pigweed Dry } \\
\text { Weight } \\
g^{z}\end{array}$} & \multirow{2}{*}{$\begin{array}{c}\text { Yield } \\
\mathrm{Mg} \mathrm{ha}^{-1 \mathrm{z}}\end{array}$} \\
\hline & & & $14 \mathrm{DAE}^{\mathrm{x}}$ & $28 \mathrm{DAE}$ & $56 \mathrm{DAE}$ & & \\
\hline Weed-free check & & $59 \mathrm{a}$ & $100 \mathrm{a}$ & $100 \mathrm{a}$ & $100 \mathrm{a}$ & $0 \mathrm{a}$ & $28 \mathrm{a}$ \\
\hline Prometryn & $\mathrm{PRE}^{\mathrm{w}}$ & \multirow{7}{*}{$46 \mathrm{abc}$} & \multirow{7}{*}{99 a } & \multirow{7}{*}{$100 \mathrm{a}$} & \multirow{7}{*}{$100 \mathrm{a}$} & \multirow{7}{*}{$0 \mathrm{a}$} & \multirow{7}{*}{$24 \mathrm{ab}$} \\
\hline Pendimethalin & PRE & & & & & & \\
\hline Glufosinate & $\mathrm{PRE}^{\mathrm{POST}} \mathrm{v}^{\mathrm{V}}$ & & & & & & \\
\hline Pyroxasulfone & POST A ${ }^{u}$ & & & & & & \\
\hline Metribuzin & POST A & & & & & & \\
\hline Acifluorfen & POST $\mathrm{B}^{\mathrm{t}}$ & & & & & & \\
\hline Oxyfluorfen & POST B & & & & & & \\
\hline Prometryn & PRE & \multirow{7}{*}{$48 \mathrm{abc}$} & \multirow{7}{*}{99 a } & \multirow{7}{*}{$77 \mathrm{a}$} & \multirow{7}{*}{$100 \mathrm{a}$} & \multirow{7}{*}{$0 \mathrm{a}$} & \multirow{7}{*}{20 abcd } \\
\hline S-Metolachlor & PRE & & & & & & \\
\hline Glufosinate & PRE/POST & & & & & & \\
\hline Pyroxasulfone & POST A & & & & & & \\
\hline Metribuzin & POST A & & & & & & \\
\hline Acifluorfen & POST B & & & & & & \\
\hline Oxyfluorfen & POST B & & & & & & \\
\hline Prometryn & PRE & \multirow{7}{*}{$15 \mathrm{ef}$} & \multirow{7}{*}{$100 \mathrm{a}$} & \multirow{7}{*}{$100 \mathrm{a}$} & \multirow{7}{*}{$100 \mathrm{a}$} & \multirow{7}{*}{$0 \mathrm{a}$} & \multirow{7}{*}{10 cde } \\
\hline Fomesafen & PRE & & & & & & \\
\hline Glufosinate & PRE/POST & & & & & & \\
\hline Pyroxasulfone & POST A & & & & & & \\
\hline Metribuzin & POST A & & & & & & \\
\hline Acifluorfen & POST B & & & & & & \\
\hline Oxyfluorfen & POST B & & & & & & \\
\hline Prometryn & PRE & \multirow{8}{*}{$11 \mathrm{ef}$} & \multirow{8}{*}{$100 \mathrm{a}$} & \multirow{8}{*}{$92 \mathrm{a}$} & \multirow{8}{*}{$100 \mathrm{a}$} & \multirow{8}{*}{$0 \mathrm{a}$} & \multirow{8}{*}{10 cde } \\
\hline$S$-metolachlor & PRE & & & & & & \\
\hline Fomesafen & PRE & & & & & & \\
\hline Glufosinate & PRE/POST & & & & & & \\
\hline Pyroxasulfone & POST A & & & & & & \\
\hline Metribuzin & POST A & & & & & & \\
\hline Acifluorfen & POST B & & & & & & \\
\hline Oxyfluorfen & POST B & & & & & & \\
\hline
\end{tabular}




\begin{tabular}{|c|c|c|c|c|c|c|c|}
\hline \multirow{2}{*}{\multicolumn{2}{|c|}{ Treatment }} & \multirow{2}{*}{$\begin{array}{c}\text { Emergence } \\
\text { carrot } \mathrm{m}^{-1} \text { row }^{\mathrm{z}}\end{array}$} & \multicolumn{3}{|c|}{ Visual Pigweed Control Ratings ${ }^{\mathrm{y}}$} & \multirow{2}{*}{$\begin{array}{c}\text { Pigweed Dry } \\
\text { Weight } \\
\mathrm{g}^{\mathrm{z}}\end{array}$} & \multirow{2}{*}{$\begin{array}{c}\text { Yield } \\
\mathrm{Mg} \mathrm{ha}^{-1} \mathrm{z}\end{array}$} \\
\hline & & & $14 \mathrm{DAE}^{\mathrm{x}}$ & $28 \mathrm{DAE}$ & $56 \mathrm{DAE}$ & & \\
\hline Prometryn & PRE & \multirow{7}{*}{33 bcde } & \multirow{7}{*}{$100 \mathrm{a}$} & \multirow{7}{*}{$95 \mathrm{a}$} & \multirow{7}{*}{$99 \mathrm{a}$} & \multirow{7}{*}{$0.01 \mathrm{a}$} & \multirow{7}{*}{$18 \mathrm{abcd}$} \\
\hline Pendimethalin & PRE & & & & & & \\
\hline Carfentrazone-ethyl & PRE/POST & & & & & & \\
\hline Pyroxasulfone & POST A & & & & & & \\
\hline Metribuzin & POST A & & & & & & \\
\hline Acifluorfen & POST B & & & & & & \\
\hline Oxyfluorfen & POST B & & & & & & \\
\hline Prometryn & PRE & \multirow{7}{*}{$17 \mathrm{def}$} & \multirow{7}{*}{$100 \mathrm{a}$} & \multirow{7}{*}{$99 \mathrm{a}$} & \multirow{7}{*}{$100 \mathrm{a}$} & \multirow{7}{*}{$0 \mathrm{a}$} & \multirow{7}{*}{9 de } \\
\hline$S$-metolachlor & PRE & & & & & & \\
\hline Carfentrazone-ethyl & PRE/POST & & & & & & \\
\hline Pyroxasulfone & POST A & & & & & & \\
\hline Metribuzin & POST A & & & & & & \\
\hline Acifluorfen & POST B & & & & & & \\
\hline Oxyfluorfen & POST B & & & & & & \\
\hline Prometryn & PRE & \multirow{7}{*}{$5 \mathrm{f}$} & \multirow{7}{*}{$100 \mathrm{a}$} & \multirow{7}{*}{99 a } & \multirow{7}{*}{$100 \mathrm{a}$} & \multirow{7}{*}{$0 \mathrm{a}$} & \multirow{7}{*}{$3 \mathrm{e}$} \\
\hline Fomesafen & PRE & & & & & & \\
\hline Carfentrazone-ethyl & PRE/POST & & & & & & \\
\hline Pyroxasulfone & POST A & & & & & & \\
\hline Metribuzin & POST A & & & & & & \\
\hline Acifluorfen & POST B & & & & & & \\
\hline Oxyfluorfen & POST B & & & & & & \\
\hline Prometryn & PRE & \multirow{8}{*}{$2 \mathrm{f}$} & \multirow{8}{*}{$100 \mathrm{a}$} & \multirow{8}{*}{$100 \mathrm{a}$} & \multirow{8}{*}{$100 \mathrm{a}$} & \multirow{8}{*}{$0 \mathrm{a}$} & \multirow{8}{*}{$2 \mathrm{e}$} \\
\hline$S$-metolachlor & PRE & & & & & & \\
\hline Fomesafen & PRE & & & & & & \\
\hline Carfentrazone-ethyl & PRE/POST & & & & & & \\
\hline Pyroxasulfone & POST A & & & & & & \\
\hline Metribuzin & POST A & & & & & & \\
\hline Acifluorfen & POST B & & & & & & \\
\hline Oxyfluorfen & POST B & & & & & & \\
\hline
\end{tabular}




\begin{tabular}{|c|c|c|c|c|c|c|c|}
\hline \multirow{2}{*}{\multicolumn{2}{|c|}{ Treatment }} & \multirow{2}{*}{$\begin{array}{c}\text { Emergence } \\
\text { carrot } \mathrm{m}^{-1} \text { row }^{\mathrm{z}}\end{array}$} & \multicolumn{3}{|c|}{ Visual Pigweed Control Ratings ${ }^{\mathrm{y}}$} & \multirow{2}{*}{$\begin{array}{c}\text { Pigweed Dry } \\
\text { Weight } \\
\text { g }^{\mathrm{z}}\end{array}$} & \multirow{2}{*}{$\begin{array}{c}\text { Yield } \\
\mathrm{Mg} \mathrm{ha}^{-1} \mathrm{z}\end{array}$} \\
\hline & & & $14 \mathrm{DAE}^{\mathrm{x}}$ & $28 \mathrm{DAE}$ & $56 \mathrm{DAE}$ & & \\
\hline Prometryn & PRE & \multirow{7}{*}{41 abcd } & \multirow{7}{*}{$99 \mathrm{a}$} & \multirow{7}{*}{$98 \mathrm{a}$} & \multirow{7}{*}{$100 \mathrm{a}$} & \multirow{7}{*}{$0 \mathrm{a}$} & \multirow{7}{*}{$21 \mathrm{abc}$} \\
\hline$S$-metolachlor & PRE & & & & & & \\
\hline Glufosinate & PRE/POST & & & & & & \\
\hline Pyroxasulfone & POST A & & & & & & \\
\hline Metribuzin & POST A & & & & & & \\
\hline Fomesafen & POST B & & & & & & \\
\hline Oxyfluorfen & POST B & & & & & & \\
\hline Prometryn & PRE & \multirow{7}{*}{$50 \mathrm{ab}$} & \multirow{7}{*}{$99 \mathrm{a}$} & \multirow{7}{*}{$98 \mathrm{a}$} & \multirow{7}{*}{$100 \mathrm{a}$} & \multirow{7}{*}{$0 \mathrm{a}$} & \multirow{7}{*}{$22 \mathrm{abc}$} \\
\hline$S$-metolachlor & PRE & & & & & & \\
\hline Glufosinate & PRE/POST & & & & & & \\
\hline Pyroxasulfone & POST A & & & & & & \\
\hline Metribuzin & POST A & & & & & & \\
\hline Fluthiacet-methyl & POST B & & & & & & \\
\hline Oxyfluorfen & POST B & & & & & & \\
\hline Prometryn & PRE & \multirow{8}{*}{$56 \mathrm{ab}$} & \multirow{8}{*}{$99 \mathrm{a}$} & \multirow{8}{*}{$98 \mathrm{a}$} & \multirow{8}{*}{$100 \mathrm{a}$} & \multirow{8}{*}{$0 \mathrm{a}$} & \multirow{8}{*}{$21 \mathrm{abcd}$} \\
\hline$S$-metolachlor & PRE & & & & & & \\
\hline Glufosinate & PRE/POST & & & & & & \\
\hline Pyroxasulfone & POST A & & & & & & \\
\hline Metribuzin & POST A & & & & & & \\
\hline Fomesafen & POST B & & & & & & \\
\hline Acifluorfen & POST B & & & & & & \\
\hline Oxyfluorfen & POST B & & & & & & \\
\hline Prometryn & PRE & \multirow{8}{*}{$45 \mathrm{abc}$} & \multirow{8}{*}{99 a } & \multirow{8}{*}{$97 \mathrm{a}$} & \multirow{8}{*}{$99 \mathrm{a}$} & \multirow{8}{*}{$0 \mathrm{a}$} & \multirow{8}{*}{$23 \mathrm{ab}$} \\
\hline$S$-metolachlor & PRE & & & & & & \\
\hline Glufosinate & PRE/POST & & & & & & \\
\hline Pyroxasulfone & POST A & & & & & & \\
\hline Metribuzin & POST A & & & & & & \\
\hline Fluthiacet-methyl & POST B & & & & & & \\
\hline Acifluorfen & POST B & & & & & & \\
\hline Oxyfluorfen & POST B & & & & & & \\
\hline
\end{tabular}




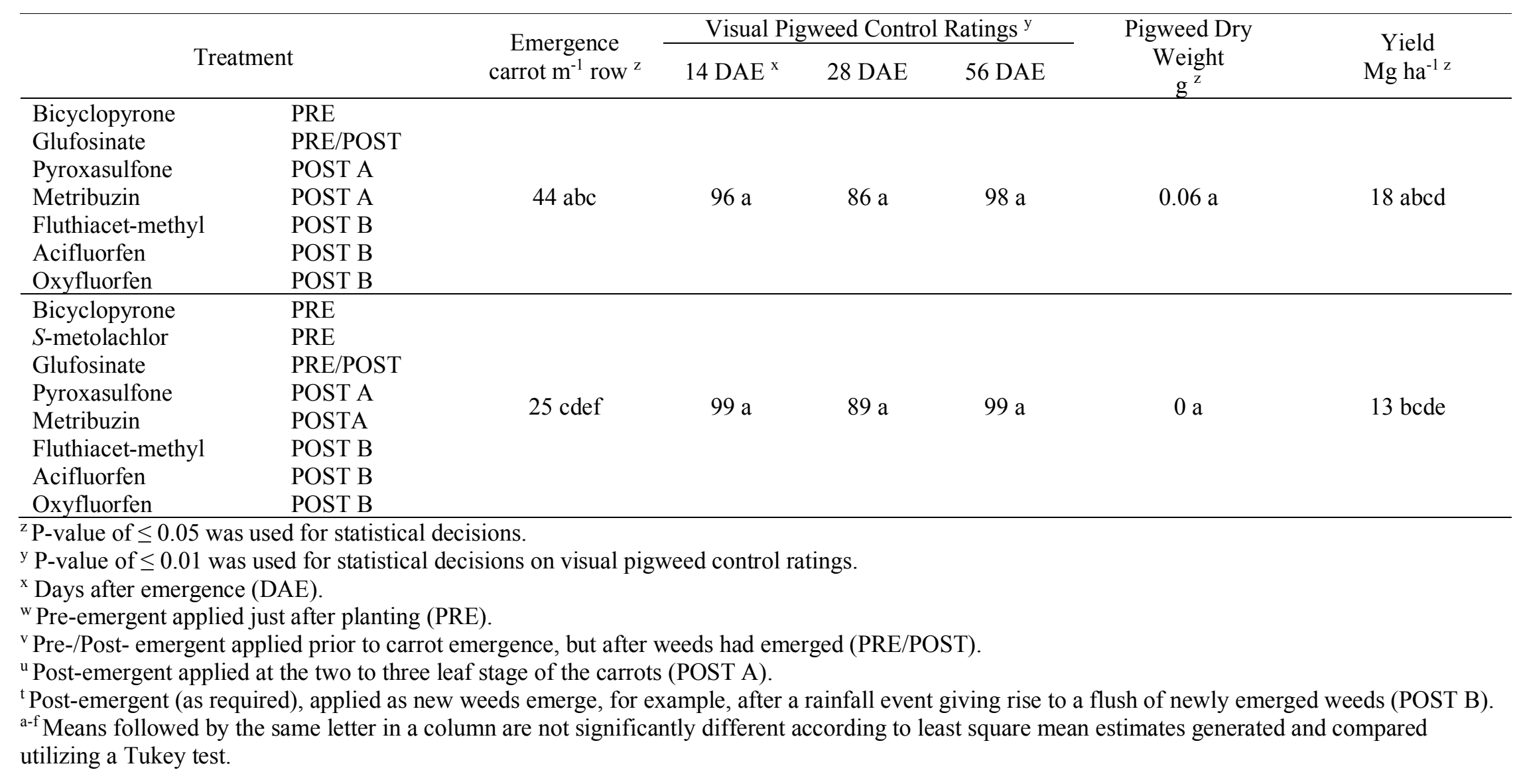




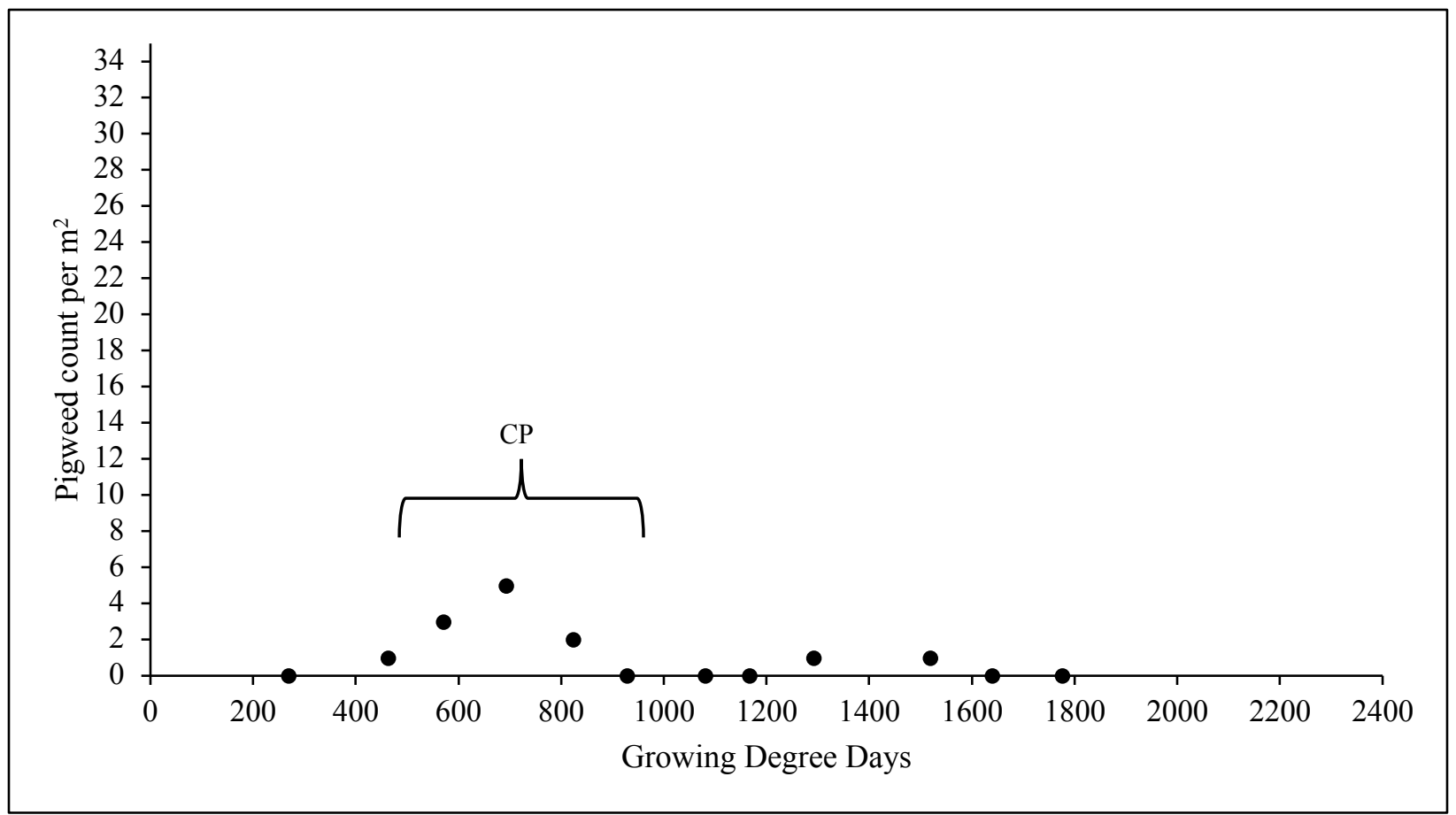

Fig. 2. 1 Pigweed seedling emergence counts per $\mathrm{m}^{2}$ associated with growing degree days for the May 20th carrot planting in 2016 at the Muck Crop Research Station near Kettleby, Ontario, Canada. The bracket indicates the critical weed-free period of carrots $(\mathrm{CP})$.

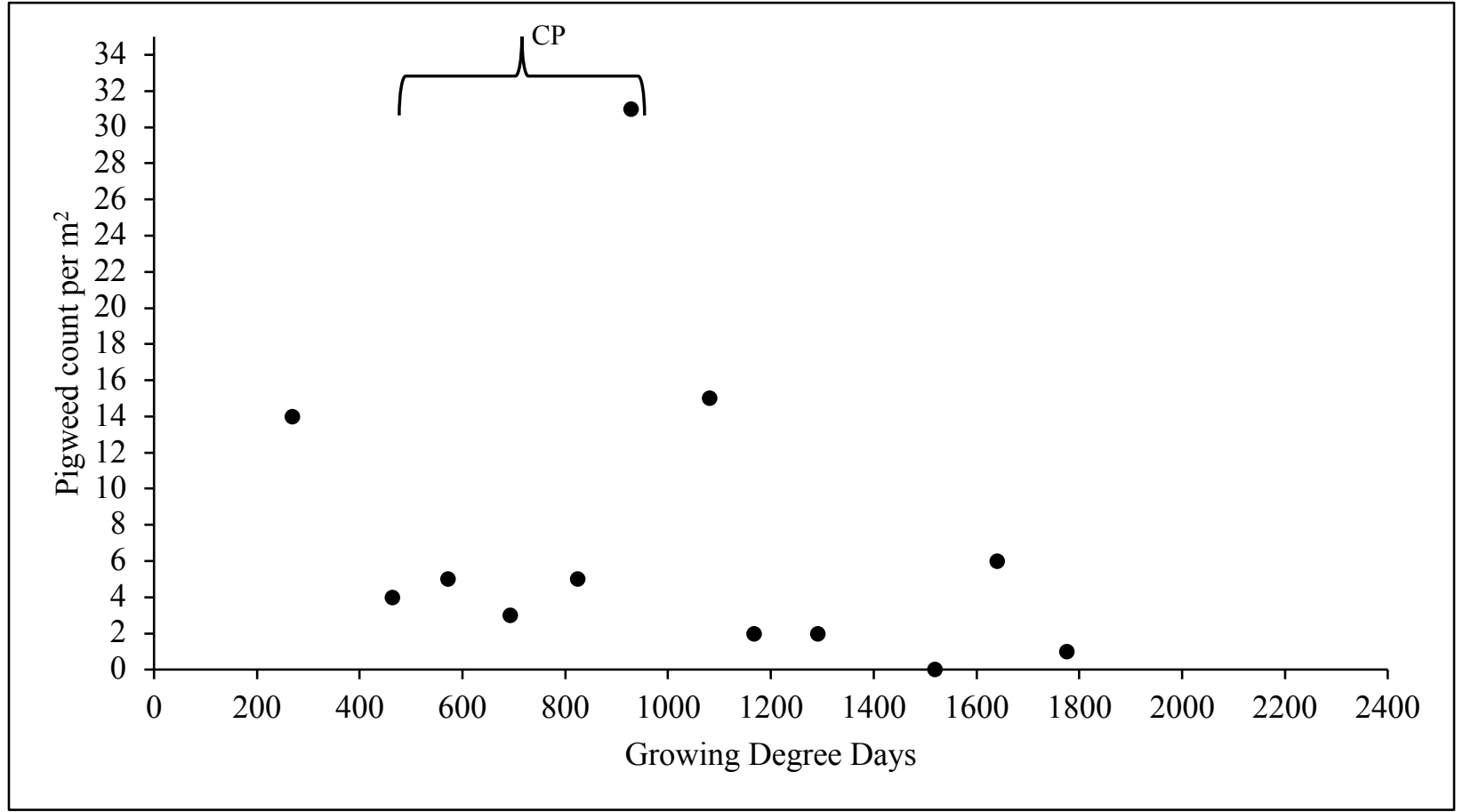

Fig. 2. 2 Pigweed seedling emergence counts from per $\mathrm{m}^{2}$ associated with growing degree days for the May $20^{\text {th }}$ carrot planting in 2016 at the Muck Crop Research Station near Kettleby, Ontario, Canada. The bracket indicates the critical weed-free period of carrots (CP). 


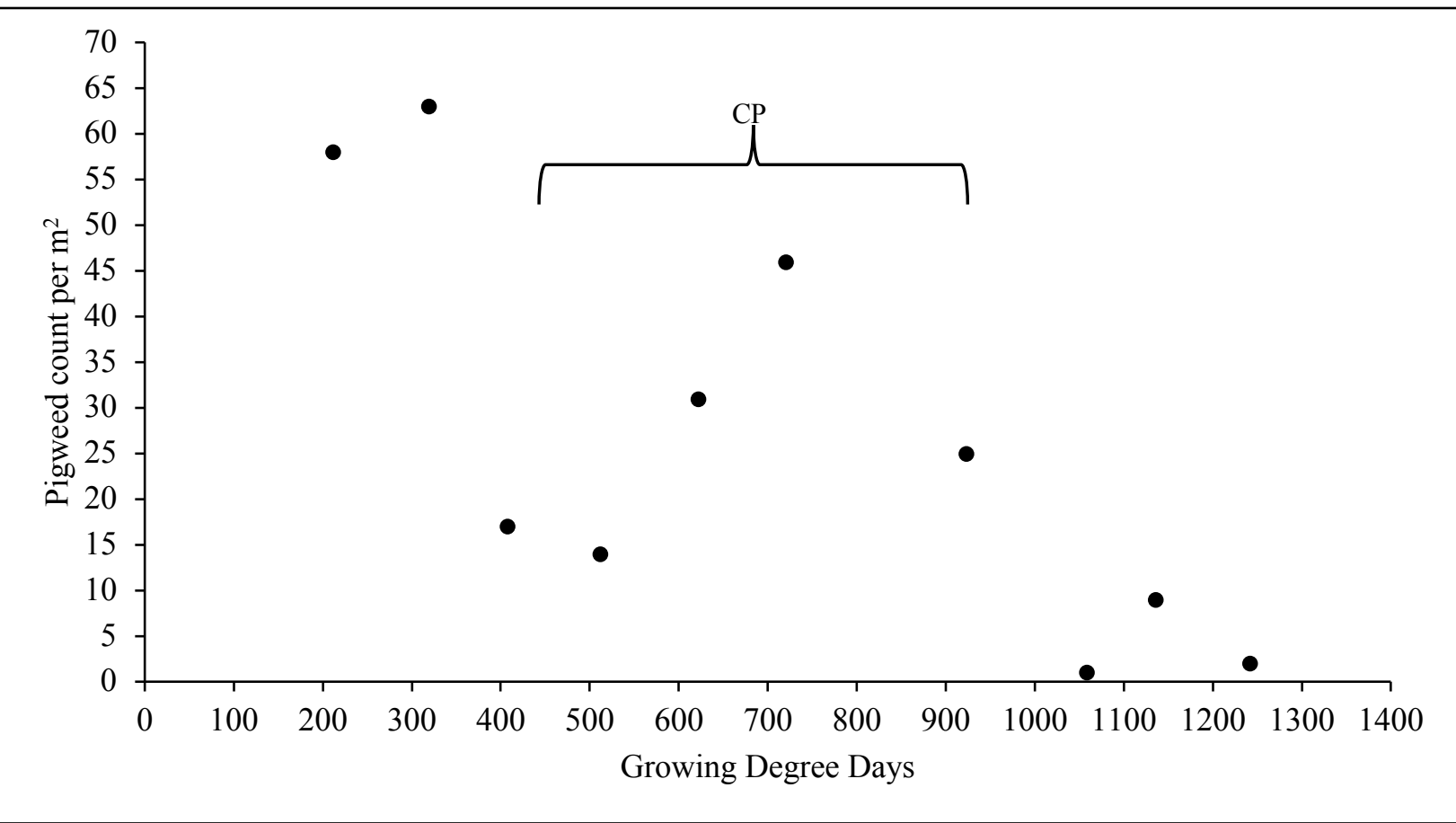

Fig. 2. 3 Pigweed seedling emergence counts per $\mathrm{m}^{2}$ associated with the May $29^{\text {th }}$ planting of carrots in 2017 at the Muck Crop Research Station located near Kettleby, Ontario, Canada. Data collection from the quadrat continued despite the loss of the carrot trial due to heavy rainfall. The bracket indicates the critical weed-free period of carrots $(\mathrm{CP})$. 


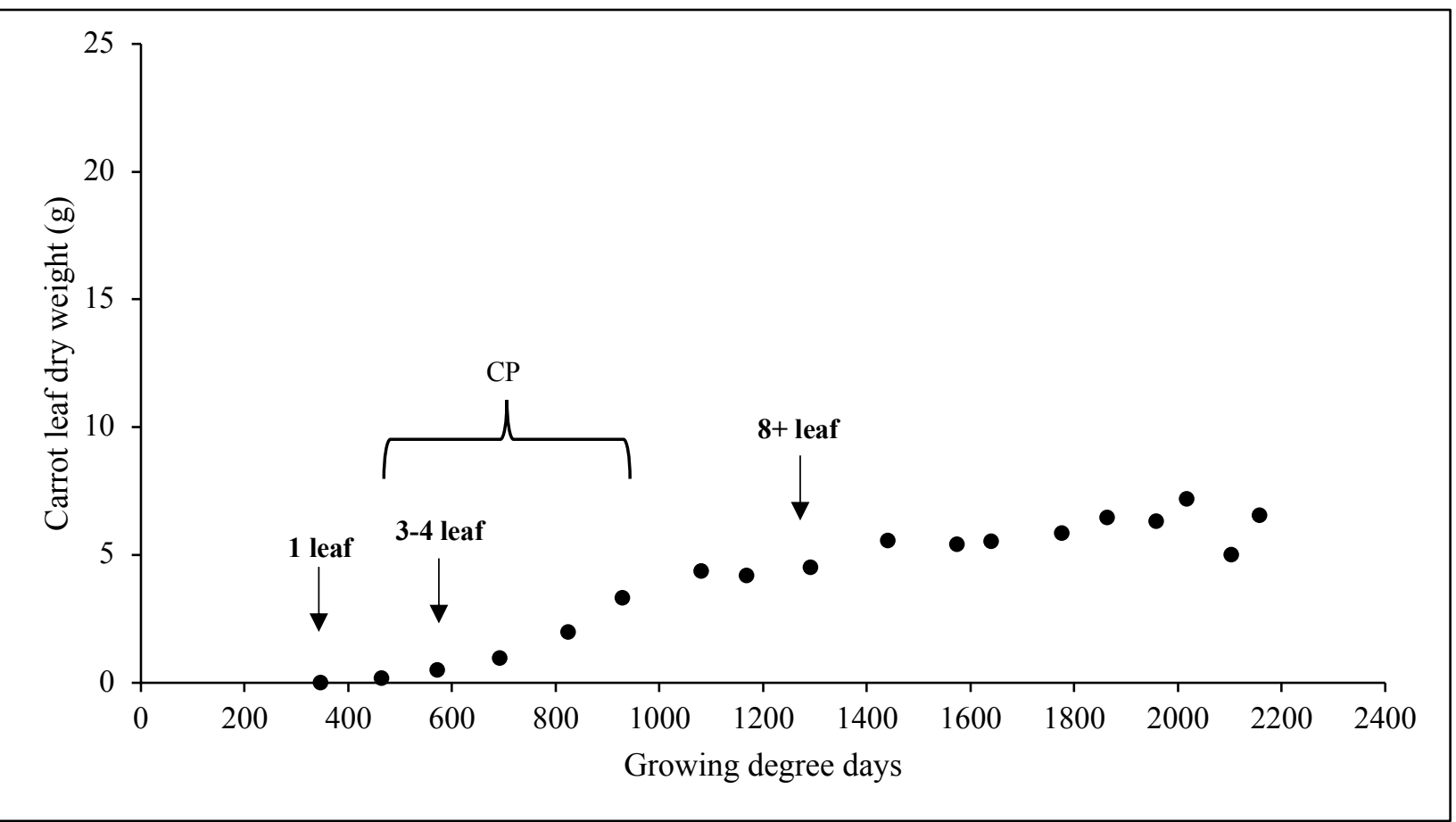

Fig. 2. 4 Carrot leaf dry weight per plant associated with growing degree days from samples taken from the Muck Crop Research Station near Kettleby, Ontario, Canada in 2016. The bracket indicates the critical weedfree period of carrots $(\mathrm{CP})$.

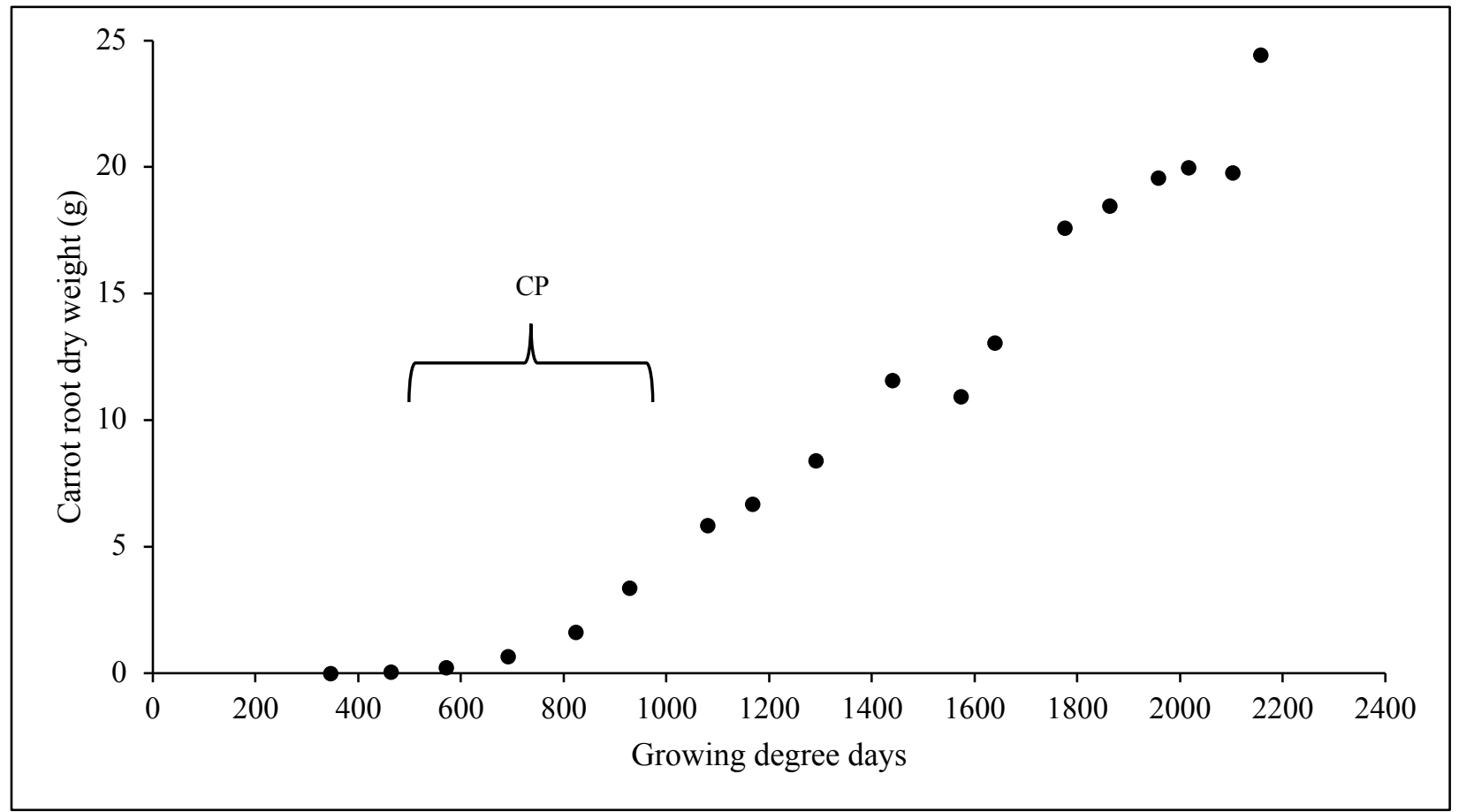

Fig. 2. 5 Carrot root dry weight per plant associated with growing degree days from samples taken from the Muck Crop Research Station near Kettleby, Ontario, Canada in 2016. The bracket indicates the critical weedfree period of carrots $(\mathrm{CP})$. 


\section{General Discussion}

\subsection{Research contribution}

Linuron is the primary herbicide upon which weed control in carrots is most dependent. Linuron can be applied pre- or post- emergent and is efficacious on a broad spectrum of weeds and stages of weed development. Linuron is also one of the few herbicides registered for use on carrots. Older herbicides, such as linuron are now under scrutiny by government regulatory agencies making the availability of these chemistries in the future uncertain. Furthermore, the overreliance on linuron has given rise to resistant pigweed species across Ontario's carrot growing regions with a parallel situation arising with common ragweed in Québec. Together, these factors make it apparent that alternatives to linuron must be found in order to keep herbicides available as a tool to maintain weed control in carrots. The preceding research has established that pigweed seedling control can be achieved without the use of linuron while maintaining commercial yields.

Over the past two years, the biologically effective dose of selected post-emergent herbicides in combination with pre-emergent herbicides made up the treatments that were tested in the field in order to find a comprehensive strategy that would control pigweed species seedlings throughout the season. The biologically effective dose was determined previously in growth room studies, but the research presented as part of this thesis, verified that these doses were also effective to control pigweed species seedlings under field conditions.

In addition to demonstrating the safety of the biologically effective dose of post emergent herbicides, the safety of selected pre-emergent herbicides was also verified. Many of the preemergent treatments successfully controlled pigweed seedlings without hindering emergence with the exception of carfentrazone-ethyl and fomesafen in the wet year of 2017. All other preand post-emergent herbicides were effective in both the hot and dry year of 2016 and the cool 
and wet year of 2017. Pre-emergence treatments of prometryn, pendimethalin, $S$-metolachlor or glufosinate followed by metribuzin and pyroxasulfone applied after weed emergence, but just before the carrots have emerged and post-emergent treatments of fomesafen, acifluorfen, oxyfluorfen, and fluthiacet-methyl were found to demonstrate excellent crop selectivity and control of pigweed seedlings

The consistency of all the herbicides besides carfentrazone-ethyl and fomesafen from year to year demonstrate that carrot growers have alternative options to linuron. If these alternative herbicides are used at the appropriate timing and as part of an integrated weed management strategy, then carrot growers will have a weed control system that could last many years into the future. The longevity of the system depends on the integration of herbicides as a component of an integrated weed management strategy or else a similar situation to what is currently being experienced with linuron resistance will arise again in the near future.

\subsection{Research limitations}

In 2017, heavy rains flooded a location where one of the carrot trials was established. As a result this trial was replanted in a different location in July. This late replanting date resulted in a much lower yield than the 2016 field season. The pending registration of pyroxasulfone on carrots and onions and oxyfluorfen on carrots creates a situation where two crops grown in rotation are utilizing the same herbicides. This invariability will lead to a greater selection pressure for resistance in the future. In addition, the biologically effective dose used in this study was developed for the control of pigweed species seedlings only. This low dose may enhance the development of resistance within the wider population of broadleaf weeds (Manalil et al. 2011). 


\subsection{Future Research}

The pigweed species population utilized in the preceding research was not confirmed to be linuron resistant. In the future, these trials should be repeated to ensure the weed control system is effective on resistant biotypes in grower fields. Research must also continue on alternative products such as pethoxamid in support of minor crop registration. Carrots cover only a small land area compared to corn or soybeans as such the drive of herbicide manufacturers to register products on carrots is low. Research helps demonstrate to these companies that their products are needed on minor crops. Another important avenue of research that must be supported in the future, is the continued development of an integrated weed management system for carrots. Currently, herbicides are heavily relied upon because hand weeding is expensive. New tools such as wick weeding and automated weeding, need to be explored to supplement herbicides and hand weeding. Most importantly, research on weed management in carrots needs to continue for the benefit of growers. 


\section{Literature Cited}

Agriculture and Agri-Food Canada (2014) Crop Profile for Carrots in Canada, 2012. http://publications.gc.ca/pub?id=9.699545\&sl=0 Accessed October 13, 2016

Agriculture and Agri-Food Canada (2015) Statistical Overview of the Canadian Vegetable Industy -2015. http://www.agr.gc.ca/eng/industry-markets-and-trade/market-informationby-sector/horticulture/horticulture-sector-reports/statistical-overview-of-the-canadianvegetable-industry-2015/?id=1478646189894\#a4.1 Accessed February 20, 2018

Anonymous (2016) Aim EC herbicide product label. FMC Corp. Philadephia, PA: FMC 21 p. Banga O (1957a) Origin of the European cultivated carrot. Euphytica 6:54-63

Banga O (1957b) The development of the original European carrot material. Euphytica 6:64-76

Bartram J, Lloyd Swail S, Mausberg B (2007) The Holland Marsh: Challenges and Opportunities in the Greenbelt. Friends of the Greenbelt Foundation Occasional Paper Series. April 2007

Bell CE, Boutwell BE, Ogbuchiekwe EJ, McGiffen ME (2000) Weed control in carrots: the efficacy and economic value of linuron. HortScience 35:1089-1091

[CFIA] Canadian Food Inspection Agency (2018) Searchable Seed Image and Illustration Library.http://inspection.gc.ca/active/netapp/idseed/idseed_gallerye.aspx?itemsNum $=\&$ famkey $=$ family $\&$ family $=$ Amaranthaceae $\&$ keyword $=\& b t n \_$submit $=$Submit\#results. Accessed: May 1, 2018.

Cobb AH, Reade JPH (2010) Chapter 12: Herbicide Resistance. Pages 216-237 in Cobbe AH, Reade JPH. Herbicides and Plant Physiology Second Edition. Chichester:WileyBlackwell. 
Costea M, Weaver SE, Tardif FJ (2004) The biology of Canadian weeds. 130. Amaranthus retroflexus L., A. powellii S. Watson and A. hybridus L. Can. J. Plant Sci. 84:631-668.

Cowbrough M, Tardif F, Letarte J (2016) Weed ID Guide for Ontario Crops. Guelph, ON: Grain Farmers of Ontario. $260 \mathrm{p}$

Crespo AM, MacRae AW, Alves C, Jacoby TP, Kelly RO (2013) Tomato root uptake of carfentrazone. Weed Tech. 27:497-501

Davis G (2014) A Survey and Characterization of Linuron-Resistant Amaranthus spp. in Southern Ontario Carrot Production. M.Sc. Thesis. Guelph, ON: University of Guelph. $89 \mathrm{p}$.

Dumont M, Letarte J, Tardif FJ (2016) Identification of a psbA mutation (Valine 219 to Isoleucine) in powell amaranth (Amaranthus powellii) conferring resistance to linuron. Weed Sci. 64:6-11

Esau K (1940) Developmental anatomy of the fleshy storage organ of Daucus carota. Hilgardia.

\section{$13: 175-226$}

Fennimore SA, Slaughter DC, Siemens MC, Leon RG, Saber MN (2016) Technology for automation of weed control in specialty crops. Weed Tech. 30:823-837

[FAO] Food and Agriculture Organization of the United Nations (2017) FAOSTAT. http://www.fao.org/faostat/en/\#data/QC Accessed: February 19, 2018

Government of Canada (2009) Re-Evaluation Program. https://www.canada.ca/en/healthcanada/services/consumer-product-safety/pesticides-pest-management/public/protectingyour-health-environment/pesticide-registration-process/reevaluation-program.html. Accessed April 2, 2018 
Heap I (2018) The International Survey of Herbicide Resistant Weeds. Available at http://www.weedscience.org/Summary/ResistByActive.aspx. Accessed March 2, 2018 Iorizzo M, Senalik DA, Ellison SL, Grzebelus D, Cavagnaro PF, Allender C, Brunet J, Spooner DM, Van Deynze A, Simon PW (2013) Genetic structure and domestication of carrot (Daucus carota subsp. sativus) (Apiaceae). Am. J. of Bot. 100:930-938.

Jensen KIN, Doohan DJ, Specht EG (2003). Response of processing carrot to metribuzin on mineral soils in Nova Scotia. Can. J. Plant Sci. 84:669-676

Knezevic SZ, Datta A (2015) The critical period for weed control: revisiting data analysis. Weed Sci. 63:188-202

Kropff MJ (1988) Modelling the effects of weed on crop production. Weed Res. 28:465-471 Mailvaganam S (2016) Agricultural Statistics for Ontario, OMAFRA; Seasonal Fruit and Vegetable Annual Summary Reports, OMAFRA; Fruit and Vegetable Survey, Statistics Canada; Ontario Processing Vegetable Growers

Manalil S, Busi R, Renton M, Powles SB (2011) Rapid evolution of herbicide resistance by low herbicide dosages. Weed Sci. 59:210-217.

Norsworthy JK, Griffith G, Griffin T, Bagavathiannan M, Gbur EE (2014) In-field movement of glyphosate-resistant palmer amaranth (Amaranthus palmeri) and its impact on cotton lint yield: evidence supporting a zero-threshold strategy. Weed Sci. 62:237-249.

Obeid K (2018) Help Us Help You: Knowing Your Enemy Will Help You Win the War. Paper presented at: 2018 Ontario Fruit and Vegetable Convention; 2018 Feb 21-22; Niagara Falls, Canada.

Obeid K, Lyse-Benoit D, Swanton CJ (2017) Best Management Practices to Control Herbicide Resistant Weeds in Carrot Production. Publisher Unknown: City Unknown. 14 p. 
Ogbuchiekwe EJ, McGiffen Jr. ME, Nunez, Fennimore SA (2004) Tolerance of Carrot to Lowrate Preemergent and Postemergent Herbicides. HortScience 39:291-296

[OMAFRA] Ontario Ministry of Agriculture, Food and Rural Affairs (2010) Vegetable Production Recommendations 2010-2011. Publication 363. Toronto: Queen's Printer for Ontario. Pp 94-99

[OMAFRA] Ontario Ministry of Agriculture, Food and Rural Affairs (2014) Vegetable Crop Protection Guide 2014-2015. Publication 838. Toronto: Queen's Printer for Ontario. Pp $61-67$

[OMAFRA] Ontario Ministry of Agriculture, Food and Rural Affairs (2015) Guide to Weed Control 2016-2017. Publication 75. Toronto: Queen's Printer for Ontario. Pp 271-275 [OMAFRA] Ontario Ministry of Agriculture, Food and Rural Affairs (2018) Guide to Weed Control, Hort Crops. Publication 75b. Toronto: Queen's Printer for Ontario. Pp 75-81

Peachey E, Doohan D, Koch T (2012) Selectivity of fomesafen based systems for preemergence weed control in cucurbit crops. Crop Prot. 40:91-91

Peruzzi A, Ginanni M, Fontanelli M, Raffaelli M, Bàrberi (2006) Innovative strategies for onfarm weed management in organic carrot. Renew. Agr. Food Syst. 22:246-259

Rong J, Lammers Y, Strasburg JL, Schidlo NS, Ariyurek Y, de Jong TJ, Klinkhamer PGL, Smulders MJM, Vrieling K (2014) New insights into domestication of carrot from root transcriptome analyses. BMC Genomics 15:895

Rosenfeld HJ, Dalen KS, Haffner K (2002) The growth and development of carrot roots. Gartenbauwissenschaft. 67:11-16

Saint-Louis S, DiTommaso A, Watson AK (2005) A common ragweed (Ambrosia artemisiifolia) biotype in Southwestern Québec resistant to linuron. Weed Tech. 19:737-743. 
Simard MJ, Laforest M, Soufiane B, Benoit DL, Tardif FJ (2017) Linuron resistant common ragweed (Ambrosia artemisiifolia) populations in Quebec carrot fields: Presence and distribution of target site and non-target site resistant biotypes. Can. J. Plant Sci. http://www.nrcresearchpress.com/doi/abs/10.1139/CJPS-2017-0163\#.Wp24f2rwaUk. Accessed December 12, 2017

Sørensen JN, Jørgensen U, Kühn BF (1997) Drought effects on the marketable and nutritional quality of carrots. J Sci. Food Agri. 74:379-391

Stephenson GR, Solomon KR (2007) Pesticides and the Environment. Canada: Canadian Network of Toxicology Centres Press. Pp 20.

Swanton CJ, O’Sullivan J, Robinson DE (2010) The critical weed-free period in carrot. Weed Sci. 58:229-233

Tesfaendrias MT, McDonald MR, Warland J (2010) Consistency of long-term marketable yield of carrot and onion cultivars in muck (organic) soil in the relation to seasonal weather. Can. J. Plant Sci. 90:755-765

Thompson WM, Nissen SJ (2002) Influence of shade and irrigation on the response of corn (Zea mays), soybean (Glycine max), and wheat (Triticum aestivum) to carfentrazoneethyl. Weed Tech. 16:314-318

Van Heemst HDJ (1985) The influence of weed competition on crop yield. Agric. Syst. 18:8193

Weaver S (2001) Pigweeds (Redroot, Green and Smooth). http://www.omafra.gov.on.ca/english /crops/facts/01-009.htm. Accessed on 5 March, 2018

[WSSA] Weed Science Society of America (2018) Herbicide Resistance. http://wssa.net/wssa/weed/resistance/. Accessed: March 2, 2018 
White JM (1992) Carrot yield when grown under three soil water concentrations. HortScience $27: 105-106$

Williams MM II, Boydston RA (2006) Volunteer potato interference in carrots. Weed Sci. 54:9499 


\section{Appendices}

\subsection{Tolerance of Onions to Treatments of Pethoxamid}

\section{Materials and Methods}

A field trial was established in 2017 at the University of Guelph Muck Crop Research Station located near Kettleby, Ontario, Canada to test onion tolerance to pre-emergent (PRE) and postemergent (POST) applications of pethoxamid at 840, 1260, 1470, $1680 \mathrm{~g}$ ai ha $^{-1}$. Tolerance of onions to doses of pethoxamid were compared to the standard POST applications of dimethenamid-p at $1080 \mathrm{~g}_{\text {ai ha }} \mathrm{h}^{-1}$ and pendimethalin at $3000 \mathrm{~g}$ ai ha ${ }^{-1}$ along with an untreated check. The trial area was spring tilled initially using a disk, followed by an application of fertilizer and two passes with a cultivator. On May $11^{\text {th }}$, onions (cultivar La Salle) were direct seeded into organic soil $(\mathrm{pH} \approx 7.1$, organic matter $\approx 63.1 \%)$ with a Stanhay precision seeder. Each plot consisted of a bed with four rows of onions spaced $42 \mathrm{~cm}$ apart and $5 \mathrm{~m}$ in length. Fertility management and disease, insect, and weed control were conducted in accordance with best management practices as described in Ontario Ministry of Agriculture publications 363 Vegetable Production Recommendations, 838 Vegetable Crop Protection Guide, and 75 Guide to Weed Contol (OMAFRA 2010; OMAFRA 2014 OMAFRA 2015).

All herbicide treatments were applied with a compressed air backpack sprayer with a threetip boom calibrated to deliver $200 \mathrm{~L} \mathrm{ha}^{-1}$ at $207 \mathrm{kPa}$ through Flat Fan TeeJet XR8002 nozzles (TeeJet Technologies, Springfield, IL, USA) spaced $50 \mathrm{~cm}$ apart. The boom height was maintained at approximately $46 \mathrm{~cm}$ above the ground or crop canopy at a walking speed of approximately $3.6 \mathrm{~km} \mathrm{~h}^{-1}$ during all herbicide applications. PRE was applied shortly after planting on May $16^{\text {th }}$ and the POST was applied May $29^{\text {th }}$ while the onions were in loop stage. 
Upon emergence, a stand count of the number of onions in a metre in the middle two rows was completed for each plot. Injury ratings were completed 7, 14, 28, and 56 days after crop emergence (DAE). Injury was rated as a percent damage compared to the untreated check with $0 \%$ denoting no injury and $100 \%$ denoting no emergence or crop death. Two $2.32 \mathrm{~m}$ yield samples were taken from each plot and combined on 28 September. Onions were graded into marketable and non-marketable yield based on size. Onions with a diameter less than $4.5 \mathrm{~cm}$ were considered non-marketable.

The trial was a randomized complete block design with each treatment replicated four times. Data was analyzed in SAS (SAS Institute, Inc., Cary, NC, Version 9.4). A mixed model analysis was completed utilizing PROC GLIMMIX. Initial variance analysis revealed no statistical significance for dose or stage*dose indicating a regression was not suitable for this data set. Stage was significant as such a least square means estimates were generated for all treatments and compared in all possible ways utilizing a Tukey test $(\mathrm{P} \leq 0.05)$. Letter codes for all pairwise comparisons were generated using the macro pdmix800.sas. A residual analysis was completed to ensure error was random, homogenous and randomly distributed. Percent visual injury values were transformed into the decimal scale, where 0 was set to 0.0001 and 1 control was set to 0.9999. All data was back transformed for presentation purposes. A Gaussian distribution with an identity link function was used in the analysis of emergence, visual injury and yield.

\section{$\underline{\text { Results and Discussion }}$}

Emergence was reduced for PRE applications of pethoxamid at 1470 and $1680 \mathrm{~g}$ ai ha ${ }^{-1}$ when compared to the untreated check (Table 5.1). Emergence was lower, but still comparable to the untreated check for pethoxamid applied PRE at 840 and $1260 \mathrm{~g}^{\text {ai ha }}{ }^{-1}$. The PRE applications were made on May $16^{\text {th }}$ and a heavy rainfall of $17 \mathrm{~mm}$ occurred on May $18^{\text {th }}$ (data not shown). 
Dhareesank et al. (2005) found that increasing soil moisture increased injury on rice in controlled laboratory experiments which could explain the injury observed on onions in the field.

Visual injury ratings were significantly different from the untreated check for pethoxamid applied PRE at all doses (Table 5.1). Pethoxamid applied POST, however, was not significantly different from the untreated check. Marketable yield of pethoxamid applied PRE at 1470 and $1680 \mathrm{~g}$ ai ha ${ }^{-1}$ yielded significantly lower than the untreated check (Table 5.1). All other treatments yielded comparably to untreated check. The results of this study indicate pethoxamid applied POST may be safe for use on onions. Additional years of data would be needed to confirm with certainty pethoxmid could be safely used under year to year weather variability.

Table 5. 1 Summary of data collected for onion tolerance to pre- and post- emergence treatments of pethoxamid in 2017 at the Muck Crop Research Station located near Kettleby, Ontario, Canada.

\begin{tabular}{|c|c|c|c|c|c|c|c|c|}
\hline \multirow[b]{2}{*}{ Herbicide } & \multirow[b]{2}{*}{ Timing } & \multirow[b]{2}{*}{$\begin{array}{l}\text { Dose } \\
\text { g ai ha }\end{array}$} & \multirow[b]{2}{*}{$\begin{array}{l}\text { Emergence } \\
\text { onions } \mathrm{m}^{-1}\end{array}$} & \multicolumn{4}{|c|}{ Visual Injury Ratings } & \multirow{2}{*}{$\begin{array}{l}\text { Yield } \\
\text { Mg ha }^{-1}\end{array}$} \\
\hline & & & & $\begin{array}{l}7 \\
\mathrm{DAE}^{\mathrm{z}}\end{array}$ & $\begin{array}{l}14 \\
\text { DAE }\end{array}$ & $\begin{array}{l}28 \\
\text { DAE }\end{array}$ & $\begin{array}{l}56 \\
\text { DAE }\end{array}$ & \\
\hline Untreated Check & -- & -- & $18 a b c$ & $0 \mathrm{~b}$ & $0 \mathrm{~b}$ & $0 \mathrm{~b}$ & $0 \mathrm{~b}$ & $72 a b c$ \\
\hline Pethoxamid & $\mathrm{PRE}^{\mathrm{y}}$ & 840 & $13 \mathrm{bcd}$ & $51 \mathrm{a}$ & $45 \mathrm{a}$ & $21 \mathrm{a}$ & $26 \mathrm{a}$ & $47 \mathrm{~cd}$ \\
\hline Pethoxamid & PRE & 1260 & $11 \mathrm{~cd}$ & $53 \mathrm{a}$ & $46 \mathrm{a}$ & $29 \mathrm{a}$ & $19 \mathrm{ab}$ & $51 \mathrm{bcd}$ \\
\hline Pethoxamid & PRE & 1470 & $9 \mathrm{~d}$ & $58 \mathrm{a}$ & $58 \mathrm{a}$ & $38 \mathrm{a}$ & $31 \mathrm{a}$ & $43 \mathrm{~d}$ \\
\hline Pethoxamid & PRE & 1680 & $9 d$ & $55 \mathrm{a}$ & $58 \mathrm{a}$ & $32 \mathrm{a}$ & $29 a$ & $45 \mathrm{~d}$ \\
\hline Pendimethalin & $\operatorname{POST}^{\mathrm{x}}$ & 3000 & $20 \mathrm{ab}$ & $0 \mathrm{~b}$ & $0 \mathrm{~b}$ & $1 \mathrm{~b}$ & $1 \mathrm{~b}$ & $78 \mathrm{ab}$ \\
\hline Dimethenamid-P & POST & 1080 & $20 \mathrm{ab}$ & $1 \mathrm{~b}$ & $3 b$ & $3 \mathrm{~b}$ & $0 \mathrm{~b}$ & $73 a b c$ \\
\hline Pethoxamid & POST & 840 & $24 \mathrm{a}$ & $0 \mathrm{~b}$ & $0 \mathrm{~b}$ & $0 \mathrm{~b}$ & $0 \mathrm{~b}$ & $81 \mathrm{a}$ \\
\hline Pethoxamid & POST & 1260 & $23 \mathrm{a}$ & $0 \mathrm{~b}$ & $0 \mathrm{~b}$ & $0 \mathrm{~b}$ & $0 \mathrm{~b}$ & $76 \mathrm{ab}$ \\
\hline Pethoxamid & POST & 1470 & $21 \mathrm{ab}$ & $0 \mathrm{~b}$ & $0 \mathrm{~b}$ & $1 \mathrm{~b}$ & $0 \mathrm{~b}$ & $81 \mathrm{a}$ \\
\hline Pethoxamid & POST & 1680 & $21 \mathrm{ab}$ & $2 b$ & $1 \mathrm{~b}$ & $1 \mathrm{~b}$ & $4 \mathrm{~b}$ & $75 \mathrm{ab}$ \\
\hline
\end{tabular}

${ }^{\mathrm{z}}$ Days after emergence (DAE).

${ }^{\mathrm{y}}$ Pre-emergent applied just after onion planting (PRE).

${ }^{x}$ Post-emergent applied when onions were in loop stage (POST).

${ }^{a-d}$ Means followed by the same letter in a column are not significantly different according to least square mean estimates generated and compared utilizing a Tukey test. 


\subsection{Tolerance of Carrots to Pethoxamid}

\section{Materials and Methods}

Field trials were established in 2016 and 2017 at the University of Guelph Muck Crop Research Station located near Kettleby, Ontario, Canada to test carrot tolerance to doses of pethoxamid on soil containing $63.1 \%$ organic matter with a $\mathrm{pH}$ of 7.1 . In 2016 , pethoxamid was applied pre-emergent (PRE) and post-emergent (POST) to carrots at doses of 840, 1260, 1470, and $1680 \mathrm{~g}$ ai ha $^{-1}$. Whereas in 2017, an additional treatment at the same dose range was applied to carrots at the cotyledon stage (BUNNY) along with treatments of s-metolachlor at doses of $1600 \mathrm{~g}_{\text {ai ha }}{ }^{-1}$ applied PRE and $1373 \mathrm{~g}$ ai ha ${ }^{-1}$ applied BUNNY and POST. In both years each trial also included an untreated check. Fertility management and disease, insect, and weed control were conducted in accordance with best management practices as described in Ontario Ministry of Agriculture publications 363 Vegetable Production Recommendations, 838 Vegetable Crop Protection Guide, and 75 Guide to Weed Contol (OMAFRA 2010; OMAFRA 2014 OMAFRA 2015).

The trial area was spring tilled initially using a disk, followed by an application of fertilizer and two passes with a cultivator. Three rows of carrots were then direct seeded at a density of approximately 66-82 seeds per metre using a Stanhay Precision Seeder (Stanhay Webb Ltd., Bourne, UK) into raised beds spaced approximately $86 \mathrm{~cm}$ apart. Each plot consisted of two carrot beds in width by $5 \mathrm{~m}$ in length. All herbicide treatments were applied with a compressed air backpack sprayer with a three-tip boom calibrated to deliver $200 \mathrm{~L} \mathrm{ha}^{-1}$ at $207 \mathrm{kPa}$ through Flat Fan TeeJet XR8002 nozzles (TeeJet Technologies, Springfield, IL, USA) spaced $50 \mathrm{~cm}$ apart. The boom height was maintained at approximately $46 \mathrm{~cm}$ above the ground or crop canopy at a walking speed of approximately $3.6 \mathrm{~km} \mathrm{~h}^{-1}$ during all herbicide applications. 
In 2016, carrot cultivar Belgrado was planted on May $24^{\text {th }}$, PRE applied May $25^{\text {th }}$, POST applied June $22^{\text {nd }}$ and harvest took place on October $6^{\text {th }}$. In 2017, carrot cultivar 2384 was planted on June $9^{\text {th }}$, PRE applied June $12^{\text {th }}$, BUNNY applied June $21^{\text {st }}$, POST applied July $6^{\text {th }}$ and harvest took place on October $17^{\text {th }}$. Data collection included carrot seedling emergence counts recorded from a $30 \mathrm{~cm}$ length of carrot row from each of the two carrots beds and then converted to number of carrots seedlings per metre of row prior to analysis. Injury ratings were taken approximately 28 and 56 days after emergence (DAE) in 2016 and 7, 14, 28, and 56 DAE in 2017. Injury was rated as a percent damage compared to the untreated check with $0 \%$ denoting no injury and $100 \%$ denoting no emergence or crop death. Carrots were harvested manually from $1.16 \mathrm{~m}$ from each of the two beds per plot and then combined for analysis. Prior to analysis, the carrots were graded into three size categories by diameter: oversized $>4.4 \mathrm{~cm}$, packaging size $2.0 \mathrm{~cm}$ to $4.4 \mathrm{~cm}$, and culls which included carrots $<2.0 \mathrm{~cm}$ in diameter, shorter than $10 \mathrm{~cm}$, forked or split carrots. In addition, insect or disease damage on carrots was disregarded while sorting. Oversized and packaging carrot weights were combined and denoted as marketable yield in $\mathrm{Mg} \mathrm{ha}^{-1}$ before statistical analysis.

The trial was a randomized complete block design with each treatment replicated four times. Unfortunately, in 2016 a severe infestation of yellow nutsedge (Cyperus esculentus L.) could not be controlled quickly enough to avoid yield damage to two replications within the trial. As such, those replications were dropped from the trial. Data was analyzed in SAS (SAS Institute, Inc., Cary, NC, Version 9.4). A mixed model analysis was completed utilizing PROC GLIMMIX. Initial variance analysis revealed no statistical significance for dose or stage*dose indicating a regression was not suitable for this data set. Stage was significant as such a least square means estimates were generated for all treatments and compared in all possible ways utilizing a Tukey 
test $(\mathrm{P} \leq 0.05)$. Letter codes for all pairwise comparisons were generated using the macro pdmix800.sas. For the 2016 data, a Gaussian distribution with an identity link function was used in the analysis of emergence, visual injury 56 DAE and yield. A lognormal distribution was used for visual injury 28 DAE. For 2017, a Gaussian distribution with an identity link function was used in the analysis of emergence, visual injury 28 DAE and yield, whereas a lognormal distribution was used for visual injury 56 DAE. A residual analysis was completed to ensure error was random, homogenous and randomly distributed. Percent visual injury values were transformed into the decimal scale, where 0 was set to 0.0001 and 1 control was set to 0.9999 . All data was back transformed for presentation purposes.

\section{$\underline{\text { Results and Discussion }}$}

In 2016, no difference in emergence, visual injury ratings at 28 and 56 DAE or yield was observed between the untreated check and treatments of pethoxamid applied PRE or POST at $840,1260,1470$, or $1680 \mathrm{~g}$ ai ha-1 (Table 5.2). In 2017, however, treatments of pethoxamid applied PRE reduced emergence and yield when compared to the untreated check (Table 5.3). There was also a significant difference between pethoxamid applied PRE and the untreated check for injury ratings taken 7, 14, 28 and 56 DAE. The different response between years can likely be attributed to the prevailing weather patterns of each year. The 2016 growing season was hot and dry, while the 2017 season was cooler and wet. Additional years of data, however, would be needed to confirm high soil moisture caused the reduction in emergence and yield for PRE treatments pethoxamid. 
Table 5. 2 Summary of data collected for carrot tolerance to pre- and post- emergence treatments of pethoxamid in 2016 at the Muck Crop Research Station located near Kettleby, Ontario, Canada.

\begin{tabular}{lllllll}
\hline \multirow{2}{*}{ Herbicide } & \multirow{2}{*}{ Timing } & $\begin{array}{l}\text { Dose } \\
\mathrm{g} \mathrm{ai} \mathrm{ha}^{-1}\end{array}$ & $\begin{array}{l}\text { Emergence } \\
\text { carrots m}^{-1}\end{array}$ & \multicolumn{2}{l}{ Visual Injury Ratings } & Yield \\
\cline { 5 - 6 } Untreated Check $^{2}$ & -- & - & $43 \mathrm{a}$ & $0 \mathrm{a}$ & $0 \mathrm{a}$ & $60 \mathrm{a}$ \\
Pethoxamid & PRE $^{\mathrm{y}}$ & 840 & $46 \mathrm{a}$ & $0 \mathrm{a}$ & $0 \mathrm{a}$ & $72 \mathrm{a}$ \\
Pethoxamid & PRE & 1260 & $44 \mathrm{a}$ & $0 \mathrm{a}$ & $0 \mathrm{a}$ & $69 \mathrm{a}$ \\
Pethoxamid & PRE & 1470 & $34 \mathrm{a}$ & $0 \mathrm{a}$ & $1 \mathrm{a}$ & $65 \mathrm{a}$ \\
Pethoxamid & PRE & 1680 & $47 \mathrm{a}$ & $0 \mathrm{a}$ & $5 \mathrm{a}$ & $66 \mathrm{a}$ \\
Pethoxamid & POST $^{\mathrm{z}}$ & 840 & $48 \mathrm{a}$ & $0 \mathrm{a}$ & $0 \mathrm{a}$ & $61 \mathrm{a}$ \\
Pethoxamid & POST & 1260 & $43 \mathrm{a}$ & $0 \mathrm{a}$ & $5 \mathrm{a}$ & $61 \mathrm{a}$ \\
Pethoxamid & POST & 1470 & $41 \mathrm{a}$ & $0 \mathrm{a}$ & $1 \mathrm{a}$ & $57 \mathrm{a}$ \\
Pethoxamid & POST & 1680 & $40 \mathrm{a}$ & $0 \mathrm{a}$ & $0 \mathrm{a}$ & $66 \mathrm{a}$ \\
\hline
\end{tabular}

${ }^{\mathrm{z}}$ Days after emergence (DAE).

${ }^{y}$ Pre-emergent applied just after carrot planting (PRE).

${ }^{\mathrm{z}}$ Post-emergent applied at the 1-3 leaf stage of the carrots (POST).

${ }^{a}$ Means followed by the same letter in a column are not significantly different according to least square mean estimates generated and compared utilizing a Tukey test.

Table 5. 3 Summary of data collected for carrot tolerance to pre- and post- emergence treatments of pethoxamid compared to an untreated check and standard treatments of s-metolachlor in 2017 at the Muck Crop Research Station located near Kettleby, Ontario, Canada.

\begin{tabular}{|c|c|c|c|c|c|c|c|c|}
\hline \multirow[b]{2}{*}{ Herbicide } & \multirow[b]{2}{*}{ Timing } & \multirow[b]{2}{*}{$\begin{array}{l}\text { Dose } \\
\text { g ai ha }\end{array}$} & \multirow[b]{2}{*}{$\begin{array}{l}\text { Emergence } \\
\text { carrots } \mathrm{m}^{-1}\end{array}$} & \multicolumn{4}{|c|}{ Visual Injury Ratings } & \multirow[b]{2}{*}{$\begin{array}{l}\text { Yield } \\
\mathrm{Mg} \mathrm{ha}^{-1}\end{array}$} \\
\hline & & & & $\begin{array}{l}7 \\
\mathrm{DAE}^{\mathrm{z}}\end{array}$ & $\begin{array}{l}14 \\
\text { DAE }\end{array}$ & $\begin{array}{l}28 \\
\text { DAE }\end{array}$ & $\begin{array}{l}56 \\
\text { DAE }\end{array}$ & \\
\hline Untreated Check & -- & -- & $55 \mathrm{a}$ & $0 \mathrm{~b}$ & $0 \mathrm{~b}$ & $0 \mathrm{~b}$ & $0 \mathrm{c}$ & $38 \mathrm{a}$ \\
\hline$S$-metolachlor & $\mathrm{PRE}^{\mathrm{y}}$ & 1600 & $35 \mathrm{~b}$ & $13 \mathrm{~b}$ & $9 \mathrm{~b}$ & $5 \mathrm{~b}$ & $1 \mathrm{abc}$ & 27 abcde \\
\hline Pethoxamid & PRE & 840 & $17 \mathrm{c}$ & $59 \mathrm{a}$ & $75 \mathrm{a}$ & $70 \mathrm{a}$ & $45 \mathrm{ab}$ & $8 \mathrm{e}$ \\
\hline Pethoxamid & PRE & 1260 & $12 \mathrm{c}$ & $86 a$ & $78 \mathrm{a}$ & $76 \mathrm{a}$ & $62 \mathrm{a}$ & 12 bcde \\
\hline Pethoxamid & PRE & 1470 & $9 \mathrm{c}$ & $83 \mathrm{a}$ & $84 \mathrm{a}$ & $81 \mathrm{a}$ & $66 \mathrm{a}$ & 9 cde \\
\hline Pethoxamid & PRE & 1680 & $9 \mathrm{c}$ & $89 a$ & $86 \mathrm{a}$ & $79 \mathrm{a}$ & $38 \mathrm{ab}$ & $8 \mathrm{de}$ \\
\hline$S$-metolachlor & BUNNY $^{\mathrm{x}}$ & 1373 & $46 \mathrm{ab}$ & $6 \mathrm{~b}$ & $2 b$ & $1 \mathrm{~b}$ & $0 \mathrm{c}$ & $32 \mathrm{ab}$ \\
\hline Pethoxamid & BUNNY & 840 & $46 \mathrm{ab}$ & $5 \mathrm{~b}$ & $4 \mathrm{~b}$ & $8 \mathrm{~b}$ & $0 \mathrm{c}$ & $29 \mathrm{abcd}$ \\
\hline Pethoxamid & BUNNY & 1260 & $48 \mathrm{ab}$ & $14 \mathrm{~b}$ & $4 \mathrm{~b}$ & $6 \mathrm{~b}$ & $0 \mathrm{c}$ & $34 \mathrm{a}$ \\
\hline Pethoxamid & BUNNY & 1470 & $46 \mathrm{ab}$ & $12 \mathrm{~b}$ & $1 \mathrm{~b}$ & $2 \mathrm{~b}$ & $0 \mathrm{c}$ & $37 \mathrm{a}$ \\
\hline Pethoxamid & BUNNY & 1680 & $46 a b$ & $6 \mathrm{~b}$ & $6 \mathrm{~b}$ & $13 \mathrm{~b}$ & $0 \mathrm{c}$ & 24 abcde \\
\hline$S$-metolachlor & POST $^{\mathrm{w}}$ & 1373 & $44 \mathrm{ab}$ & $8 \mathrm{~b}$ & $0 \mathrm{~b}$ & $4 \mathrm{~b}$ & $0 \mathrm{c}$ & $33 \mathrm{ab}$ \\
\hline Pethoxamid & POST & 840 & $48 \mathrm{ab}$ & $12 \mathrm{~b}$ & $1 \mathrm{~b}$ & $2 b$ & $0 \mathrm{bc}$ & 27 abcde \\
\hline Pethoxamid & POST & 1260 & $47 \mathrm{ab}$ & $8 \mathrm{~b}$ & $0 \mathrm{~b}$ & $3 \mathrm{~b}$ & $0 \mathrm{c}$ & 25 abcde \\
\hline Pethoxamid & POST & 1470 & $43 a b$ & $9 \mathrm{~b}$ & $0 \mathrm{~b}$ & $4 \mathrm{~b}$ & $0 \mathrm{c}$ & 25 abcde \\
\hline Pethoxamid & POST & 1680 & $48 \mathrm{ab}$ & $2 \mathrm{~b}$ & $0 \mathrm{~b}$ & $1 \mathrm{~b}$ & $0 \mathrm{c}$ & $29 a b c$ \\
\hline
\end{tabular}

${ }^{\mathrm{z}}$ Days after emergence (DAE).

${ }^{y}$ Pre-emergent applied just after carrot planting (PRE).

${ }^{x}$ Herbicide application made at the cotyledon stage of carrot growth characterized by the "bunny ear" appearance of the first two leaves (BUNNY).

${ }^{\text {w }}$ Post-emergent applied at the 2-3 leaf stage of the carrots (POST). 
${ }^{\mathrm{a}-\mathrm{e}}$ Means followed by the same letter in a column are not significantly different according to least square mean estimates generated and compared utilizing a Tukey test. 


\subsection{Tolerance of Carrots to Pyroxasulfone}

\section{Materials and Methods}

Field trials were established in 2016 and 2017 at the University of Guelph Muck Crop Research Station located near Kettleby, Ontario, Canada to test carrot tolerance to doses of pyroxasulfone on soil containing $63.1 \%$ organic matter with a $\mathrm{pH}$ of 7.1 . In 2016 , pyroxasulfone was applied pre-emergent (PRE) and post-emergent (POST) to carrots. Whereas in 2017, an additional treatment at the cotyledon stage (BUNNY) was added. In both years each trial also included an untreated check. Treatment details are listed in Tables 5.4 and 5.5 Fertility management and disease, insect, and weed control were conducted in accordance with best management practices as described in Ontario Ministry of Agriculture publications 363 Vegetable Production Recommendations, 838 Vegetable Crop Protection Guide, and 75 Guide to Weed Contol (OMAFRA 2010; OMAFRA 2014 OMAFRA 2015).

The trial area was spring tilled initially using a disk, followed by an application of fertilizer and two passes with a cultivator. Three rows of carrots were then direct seeded at a density of approximately 66-82 seeds per metre using a Stanhay Precision Seeder (Stanhay Webb Ltd., Bourne, UK) into raised beds spaced approximately $86 \mathrm{~cm}$ apart. Each plot consisted of two carrot beds in width by $5 \mathrm{~m}$ in length. All herbicide treatments were applied with a compressed air backpack sprayer with a three-tip boom calibrated to deliver $200 \mathrm{~L} \mathrm{ha}^{-1}$ at $207 \mathrm{kPa}$ through Flat Fan TeeJet XR8002 nozzles (TeeJet Technologies, Springfield, IL, USA) spaced $50 \mathrm{~cm}$ apart. The boom height was maintained at approximately $46 \mathrm{~cm}$ above the ground or crop canopy at a walking speed of approximately $3.6 \mathrm{~km} \mathrm{~h}^{-1}$ during all herbicide applications.

In 2016, carrot cultivar Belgrado was planted on May $24^{\text {th }}$, PRE applied May $25^{\text {th }}$, POST applied June $22^{\text {nd }}$ and harvest took place on October $6^{\text {th }}$. In 2017, carrot cultivar 2384 was planted on June $9^{\text {th }}$, PRE applied June $12^{\text {th }}$, BUNNY applied June $21^{\text {st }}$, POST applied July $6^{\text {th }}$ and 
harvest took place on October $17^{\text {th }}$. Data collection included carrot seedling emergence counts recorded from a $30 \mathrm{~cm}$ length of carrot row from each of the two carrots beds and then converted to number of carrots seedlings per metre of row prior to analysis. Injury ratings were taken approximately 14 and 56 days after emergence (DAE) in 2016 and 7, 14, and 56 DAE in 2017. Injury was rated as a percent damage compared to the untreated check with $0 \%$ denoting no injury and $100 \%$ denoting no emergence or crop death. Carrots were harvested manually from $1.16 \mathrm{~m}$ from each of the two beds per plot and then combined for analysis. Prior to analysis, the carrots were graded into three size categories by diameter: oversized $>4.4 \mathrm{~cm}$, packaging size $2.0 \mathrm{~cm}$ to $4.4 \mathrm{~cm}$, and culls which included carrots $<2.0 \mathrm{~cm}$ in diameter, shorter than $10 \mathrm{~cm}$, forked or split carrots. In addition, insect or disease damage on carrots was disregarded while sorting. Oversized and packaging carrot weights were combined and denoted as marketable yield in $\mathrm{Mg} \mathrm{ha}^{-1}$ before statistical analysis.

The trial was a randomized complete block design with each treatment replicated four times. Data was analyzed in SAS (SAS Institute, Inc., Cary, NC, Version 9.4). A mixed model analysis was completed utilizing PROC GLIMMIX. Initial variance analysis revealed no statistical significance for dose or stage*dose indicating a regression was not suitable for this data set. Stage was significant as such a least square means estimates were generated for all treatments and compared in all possible ways utilizing a Tukey test $(\mathrm{P} \leq 0.05)$. Letter codes for all pairwise comparisons were generated using the macro pdmix800.sas. A Gaussian distribution with an identity link function was used in the analysis of emergence and yield for both years. A beta distribution with a logit link function was used for visual injury rating completed 14 DAE in 2016 and 7 and 56 DAE in 2017. A lognormal distribution with an identity link function was used for visual injury ratings completed 56 DAE in 2016 and 14 DAE in 2017. A residual 
analysis was completed to ensure error was random, homogenous and randomly distributed.

Percent visual injury values were transformed into the decimal scale, where 0 was set to 0.0001

and 1 control was set to 0.9999 . All data was back transformed for presentation purposes.

\section{$\underline{\text { Results and Discussion }}$}

In 2016, some difference in emergence was apparent, but only PRE applications of

pyroxasulfone at $250 \mathrm{~g}_{\text {ai ha }}{ }^{-1}$ was significantly different from the untreated check (Table 5.4).

Differences were not observed when visual injury ratings were taken 14 and 56 DAE or in the

final yield. In 2017, results were more variable, with PRE application of pyroxasulfone at $89 \mathrm{~g}$ ai

$\mathrm{ha}^{-1}$ reducing yield compared to the untreated check. Again, this was likely due to the wet

growing season of 2017 compared to the hot and dry season of 2016.

Table 5. 4 Summary of data collected for carrot tolerance to pre- and post- emergence treatments of pyroxasulfone compared to an untreated check and standard treatment of s-metolachlor in 2016 at the Muck Crop Research Station located near Kettleby, Ontario, Canada.

\begin{tabular}{|c|c|c|c|c|c|c|}
\hline \multirow{2}{*}{ Herbicide } & \multirow{2}{*}{ Timing } & \multirow{2}{*}{$\begin{array}{l}\text { Dose } \\
\mathrm{g} \mathrm{ai} \mathrm{ha}^{-1}\end{array}$} & \multirow{2}{*}{$\begin{array}{l}\text { Emergence } \\
\text { carrots } \mathrm{m}^{-1}\end{array}$} & \multicolumn{2}{|c|}{ Visual Injury Ratings } & \multirow{2}{*}{$\begin{array}{l}\text { Yield } \\
\text { Mg ha }^{-1}\end{array}$} \\
\hline & & & & $14 \mathrm{DAE}^{\mathrm{z}}$ & $56 \mathrm{DAE}$ & \\
\hline Untreated Check & -- & -- & $55 \mathrm{a}$ & $0 \mathrm{a}$ & $0 \mathrm{a}$ & $83 \mathrm{a}$ \\
\hline$S$-metolachlor & $\mathrm{PRE}^{\mathrm{y}}$ & 1373 & $45 \mathrm{abc}$ & $6 \mathrm{a}$ & $0 \mathrm{a}$ & $82 \mathrm{a}$ \\
\hline Pyroxasulfone & PRE & 89 & $39 \mathrm{abc}$ & $4 \mathrm{a}$ & $0 \mathrm{a}$ & $75 \mathrm{a}$ \\
\hline Pyroxasulfone & PRE & 100 & $49 \mathrm{abc}$ & $4 \mathrm{a}$ & $0 \mathrm{a}$ & $76 \mathrm{a}$ \\
\hline Pyroxasulfone & PRE & 125 & $46 \mathrm{abc}$ & $4 \mathrm{a}$ & $0 \mathrm{a}$ & $76 a$ \\
\hline Pyroxasulfone & PRE & 178 & $32 \mathrm{bc}$ & $12 \mathrm{a}$ & $0 \mathrm{a}$ & $70 \mathrm{a}$ \\
\hline Pyroxasulfone & PRE & 200 & $45 \mathrm{abc}$ & $7 \mathrm{a}$ & $0 \mathrm{a}$ & $85 \mathrm{a}$ \\
\hline Pyroxasulfone & PRE & 250 & $30 \mathrm{c}$ & $16 \mathrm{a}$ & $0 \mathrm{a}$ & $70 \mathrm{a}$ \\
\hline Pyroxasulfone & $\operatorname{POST}^{x}$ & 89 & $55 \mathrm{a}$ & $0 \mathrm{a}$ & $0 \mathrm{a}$ & $89 \mathrm{a}$ \\
\hline Pyroxasulfone & POST & 100 & $47 \mathrm{abc}$ & $4 \mathrm{a}$ & $0 \mathrm{a}$ & $85 \mathrm{a}$ \\
\hline Pyroxasulfone & POST & 125 & $51 \mathrm{ab}$ & $0 \mathrm{a}$ & $0 \mathrm{a}$ & $78 \mathrm{a}$ \\
\hline Pyroxasulfone & POST & 178 & $52 \mathrm{ab}$ & $3 a$ & $0 \mathrm{a}$ & $78 \mathrm{a}$ \\
\hline Pyroxasulfone & POST & 200 & $44 a b c$ & $2 \mathrm{a}$ & $0 \mathrm{a}$ & $84 \mathrm{a}$ \\
\hline Pyroxasulfone & POST & 250 & $44 a b c$ & $5 \mathrm{a}$ & $0 \mathrm{a}$ & $77 \mathrm{a}$ \\
\hline
\end{tabular}

${ }^{\mathrm{z}}$ Days after emergence (DAE).

${ }^{\mathrm{y}}$ Pre-emergent applied just after carrot planting (PRE).

${ }^{\mathrm{z}}$ Post-emergent applied at the 1-3 leaf stage of the carrots (POST).

${ }^{a}$ Means followed by the same letter in a column are not significantly different according to least square mean estimates generated and compared utilizing a Tukey test. 
Table 5. 5 Summary of data collected for carrot tolerance to pre-emergence, bunny stage, and post-emergence treatments of pyroxasulfone compared to an untreated check in 2017 at the Muck Crop Research Station located near Kettleby, Ontario, Canada.

\begin{tabular}{|c|c|c|c|c|c|c|c|}
\hline \multirow{2}{*}{ Herbicide } & \multirow{2}{*}{ Timing } & \multirow{2}{*}{$\begin{array}{l}\text { Dose } \\
\text { g ai ha }{ }^{-1}\end{array}$} & \multirow{2}{*}{$\begin{array}{l}\text { Emergence } \\
\text { carrots } \mathrm{m}^{-1}\end{array}$} & \multicolumn{3}{|c|}{ Visual Injury Ratings } & \multirow{2}{*}{$\begin{array}{l}\text { Yield } \\
\text { Mg ha }^{-1}\end{array}$} \\
\hline & & & & $7 \mathrm{DAE}^{\mathrm{z}}$ & $14 \mathrm{DAE}$ & $56 \mathrm{DAE}$ & \\
\hline Untreated Check & -- & -- & $55 \mathrm{ab}$ & $0 \mathrm{ab}$ & $0 \mathrm{~b}$ & $0 \mathrm{ab}$ & $38 \mathrm{a}$ \\
\hline Pyroxasulfone & $\mathrm{PRE}^{\mathrm{y}}$ & 89 & $24 \mathrm{c}$ & $29 \mathrm{a}$ & $15 \mathrm{a}$ & $17 \mathrm{a}$ & $20 \mathrm{~b}$ \\
\hline Pyroxasulfone & BUNNY ${ }^{x}$ & 89 & $43 \mathrm{bc}$ & $3 \mathrm{~b}$ & $0 \mathrm{~b}$ & $1 \mathrm{~b}$ & $33 a b$ \\
\hline Pyroxasulfone & BUNNY & 178 & $49 a b$ & $3 \mathrm{~b}$ & $5 \mathrm{a}$ & $0 \mathrm{ab}$ & $22 \mathrm{ab}$ \\
\hline Pyroxasulfone & POST $^{\mathrm{w}}$ & 89 & $64 \mathrm{a}$ & $3 \mathrm{~b}$ & $0 \mathrm{~b}$ & $0 \mathrm{ab}$ & $25 \mathrm{ab}$ \\
\hline
\end{tabular}

${ }^{\mathrm{z}}$ Days after emergence (DAE).

y Pre-emergent applied just after carrot planting (PRE).

${ }^{\mathrm{x}}$ Herbicide application made at the cotyledon stage of carrot growth characterized by the "bunny ear" appearance of the first two leaves (BUNNY).

${ }^{\mathrm{w}}$ Post-emergent applied at the 2-3 leaf stage of the carrots (POST).

${ }^{\mathrm{a}-\mathrm{c}}$ Means followed by the same letter in a column are not significantly different according to least square mean estimates generated and compared utilizing a Tukey test. 


\subsection{Optimization of Wick Weeding Technology}

\section{Materials and Methods}

Field trials were established in 2016 and 2017 at the University of Guelph Muck Crop Research Station located near Kettleby, Ontario, Canada to test the effectiveness of wick weeding technology on a stand of weeds in the absence of a crop. A wick weeder (Smucker Manufacturing Inc., Harrisburg, OR) is a foam roller that is saturated with herbicide (Figure 5.1). The wick weeder can be attached to a piece of farm equipment such as a sprayer to move across the field (Figure 5.2). The roller makes contact with the weeds, coating the weeds with herbicide. If wick weeding were to take place in the presence of a crop, the weeds would have to be taller than the crop canopy so the wick weeder could coat the weeds with herbicide while leaving the crop untouched. In 2016, two trials were established; one on tall weeds (average height $=46 \mathrm{~cm}$ ) and one on short weeds (average height $=28 \mathrm{~cm}$ ). Whereas in 2017 only one trial was established (average height $=33 \mathrm{~cm}$ ). In 2016, wicking of the tall weeds took place on August $3^{\text {rd }}$ and the short weeds on August $23^{\text {rd }}$ and in 2017 wicking took place on July $31^{\text {st }}$. The wick weeder was attached to a sprayer in 2016 . Whereas in 2017, the wick was attached to a bar that could be handheld by two operators (Figure 5.3). Weed biomass harvest took place approximately 21 days after herbicide application. Weed biomass was dried to a consistent weight at $80^{\circ} \mathrm{C}$ and then compared across treatments.

The trial was a randomized complete block design with each treatment replicated four times. Data was analyzed in SAS (SAS Institute, Inc., Cary, NC, Version 9.4). A mixed model analysis was completed utilizing PROC GLIMMIX. Least square means estimates were generated for all treatments and compared in all possible ways utilizing a Tukey test $(\mathrm{P} \leq 0.05)$. Letter codes for all pairwise comparisons were generated using the macro pdmix800.sas. A Gaussian distribution 
with an identity link function was used for each data set. A residual analysis was completed to ensure error was random, homogenous and randomly distributed.

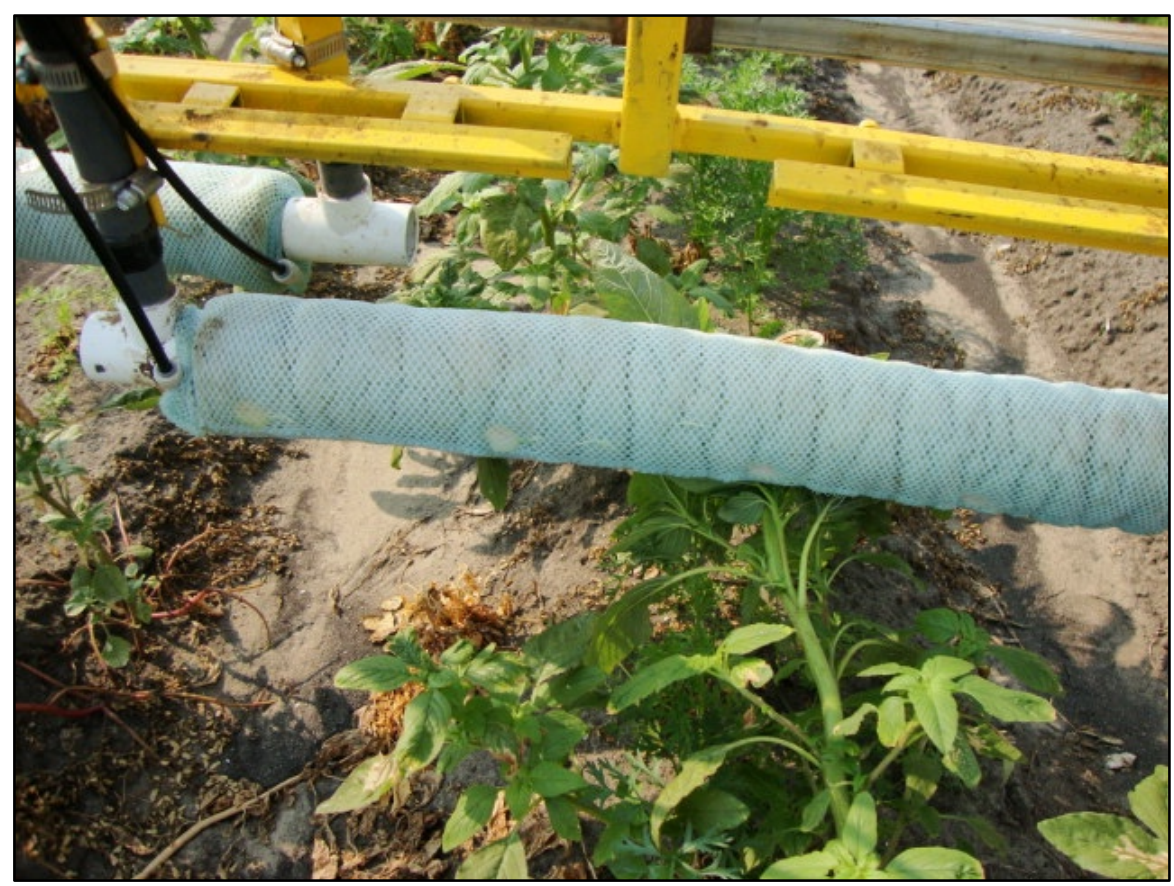

Fig. 5. 1 The wick roller that is attached to the wick weeder.

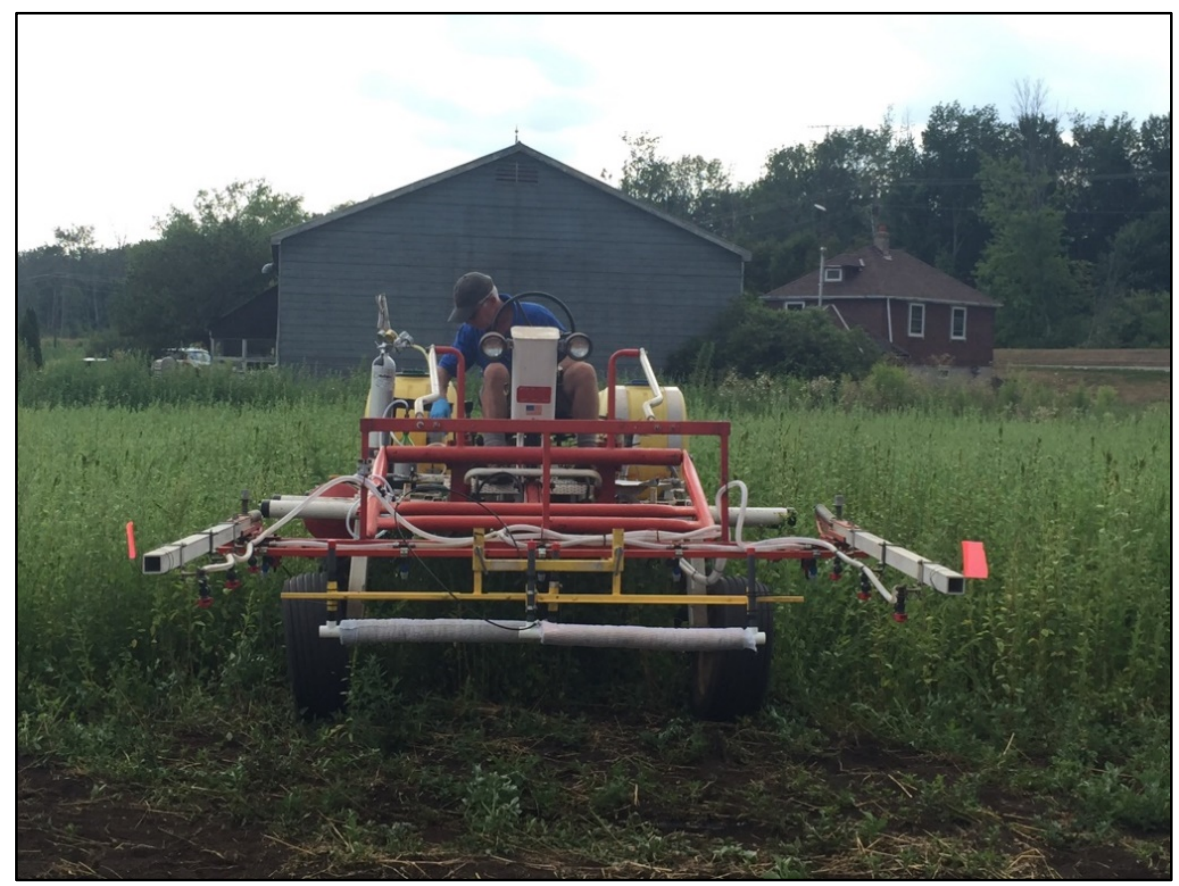

Fig. 5. 2 The wick weeder attached to a plot sprayer that was used for trials in 2016 . 


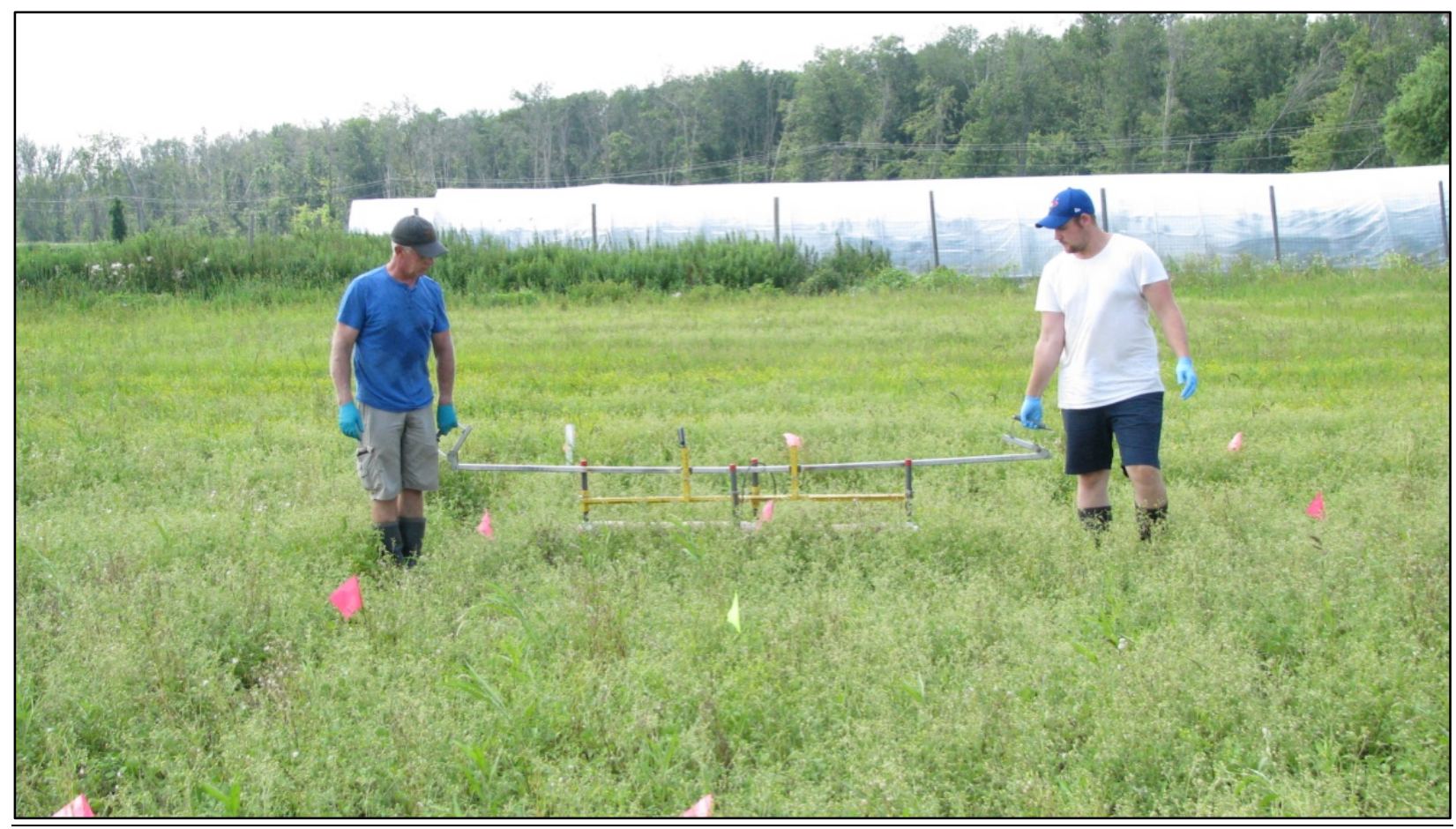

Fig. 5. 3 Wick Weeding with the handheld bar with the wick weeder attached.

\section{$\underline{\text { Results }}$}

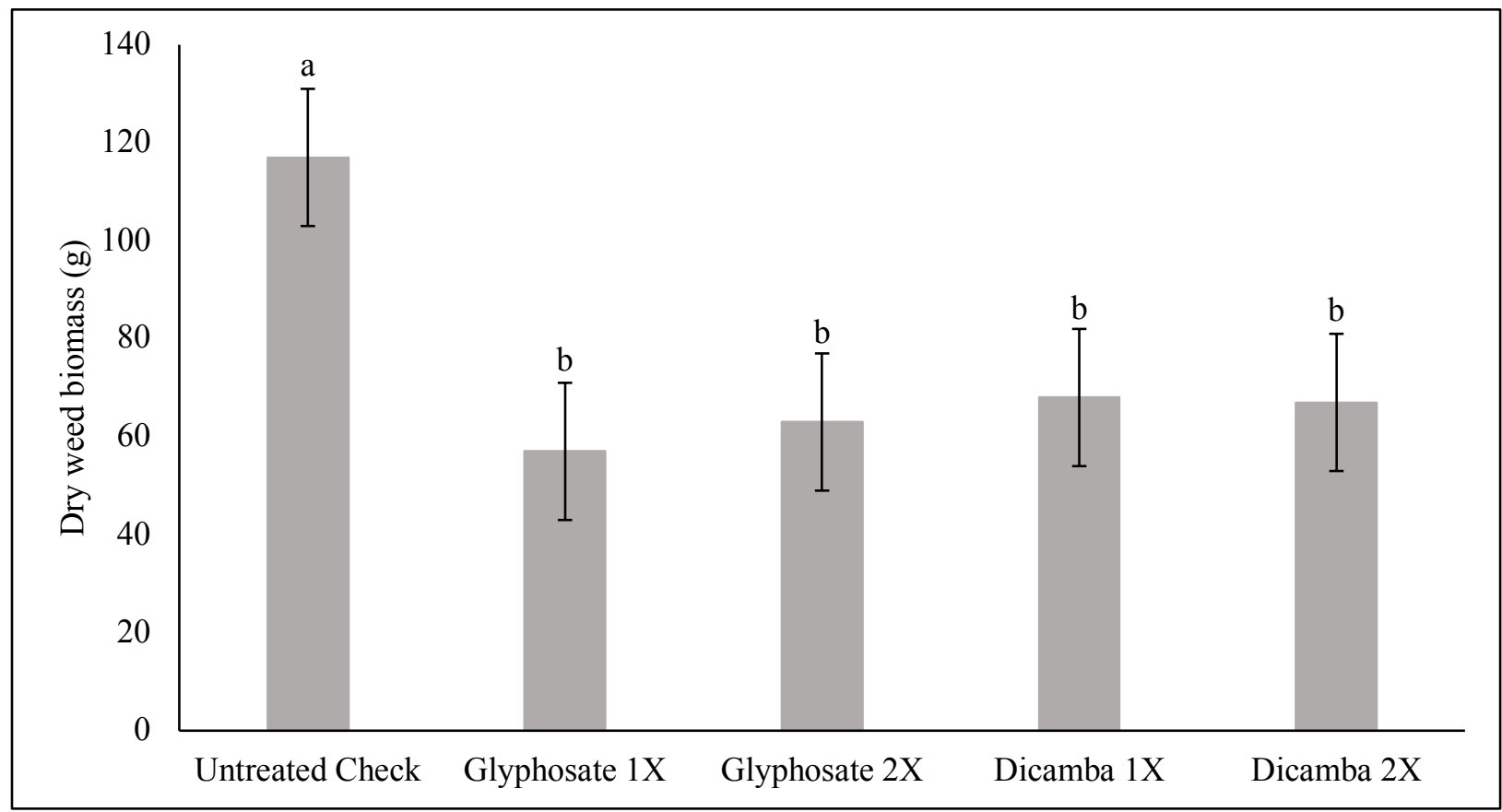

Fig. 5. 4 Dry weed biomass for wick weeding that occurred on tall weeds at the Muck Crop Research Station located near Kettleby, Ontario, Canada in 2016. 


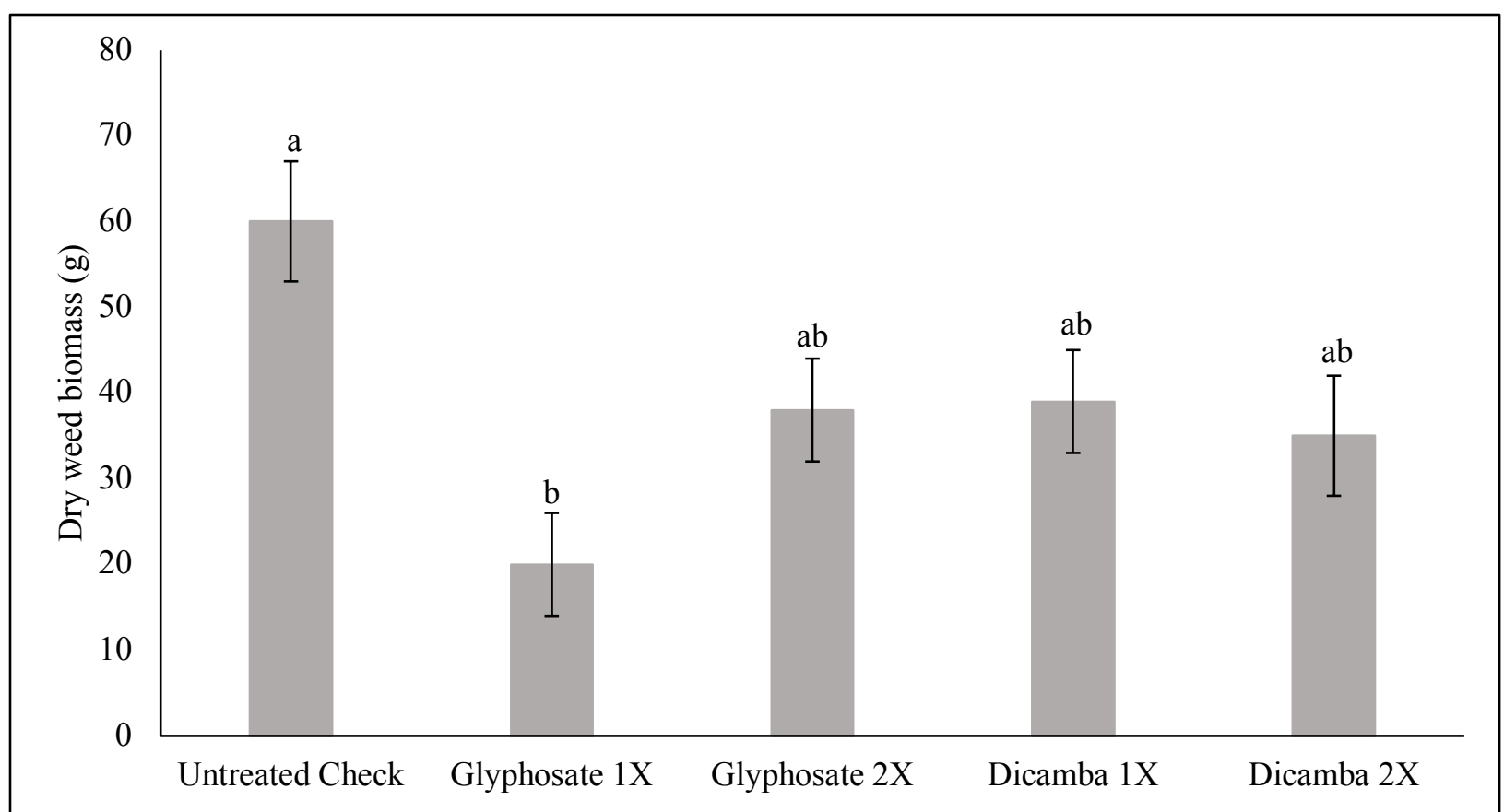

Fig. 5. 5 Dry weed biomass for wick weeding that occurred on short weeds at the Muck Crop Research Station located near Kettleby, Ontario, Canada in 2016.

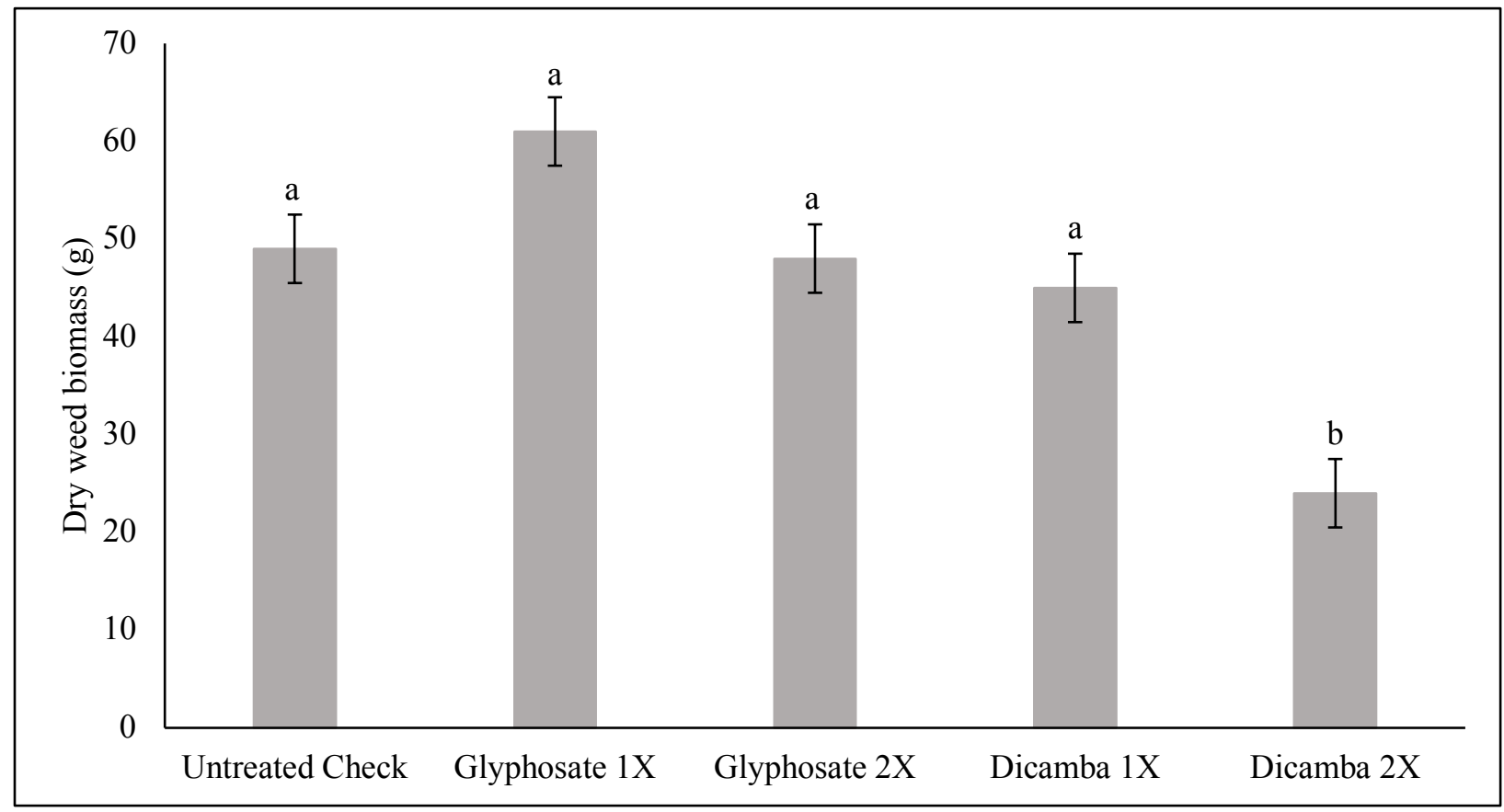

Fig. 5. 6 Dry weed biomass for wick weeding that occurred on weeds at the Muck Crop Research Station located near Kettleby, Ontario, Canada in 2017. 


\subsection{Literature Cited}

Dhareesank A, Kobayashi K, Usui K (2005) Phytotoxic activity of pethoxamid in soil under different moisture conditions. Weed Biol. Manag. 5:197-202.

[OMAFRA] Ontario Ministry of Agriculture, Food and Rural Affairs (2010) Vegetable Production Recommendations 2010-2011. Publication 363. Toronto: Queen's Printer for Ontario. $243 \mathrm{p}$

[OMAFRA] Ontario Ministry of Agriculture, Food and Rural Affairs (2014) Vegetable Crop Protection Guide 2014-2015. Publication 838. Toronto: Queen’s Printer for Ontario. 272 $\mathrm{p}$

[OMAFRA] Ontario Ministry of Agriculture, Food and Rural Affairs (2015) Guide to Weed Control 2016-2017. Publication 75. Toronto: Queen’s Printer for Ontario. 457 p 